Article

\title{
The Knowledge Mapping of Mobile Commerce Research: A Visual Analysis Based on I-Model
}

\author{
Shan $\mathrm{Du}^{1,2}$ and Hua $\mathrm{Li}^{1,2, *}$ \\ 1 School of Economics \& Management, Xidian University, Xi'an 710071, China; dushan_19860617@126.com \\ 2 Shaanxi Soft Science Institute of Informatization and Digita Economy, Xidian University, Xi'an 710071, China \\ * Correspondence: lihua@xidian.edu.cn; Tel.: +86-139-9113-2198
}

Received: 9 February 2019; Accepted: 7 March 2019; Published: 15 March 2019

\begin{abstract}
With the advance of 5G communication technologies and Internet+ strategy, mobile commerce has experienced rapid growth and needs urgent attention from researchers. It is the aim of this article to analyze the literature on mobile commerce to address the following question: With the wide application of artificial intelligence and big data, what are the latest technology, models and problems in the background of the new era that researchers and practitioners need to understand in order to grasp the research frontier in this field quickly? Therefore, to achieve these objectives, this paper reviews $1130 \mathrm{~m}$-commerce articles with 25,502 associated references from the SCI-EXPANDED, SSCI, CPCI-S, CPCI-SSH database and develops a framework of m-commerce value by analyzing the most influential authors, institutions, countries, journals and keywords in $\mathrm{m}$-commerce. We apply three types of knowledge mapping to our study-cluster view, timezone view and timeline view. Frequency statistics, clustering coefficient as well as centrality calculation are employed to analyze by CiteSpace. We use the strength of citation bursts to analyze keywords and put result into the I-Modelwhich provide an important framework for classifying $\mathrm{m}$-commerce activities and theories. In this study, we explore the knowledge structure, development and the future trend of mobile commerce for researchers. We identify the main technology and models to improve customer satisfaction and adoption behavior in the background of the new era which provide decision support for practitioners. Compared with the existing literature reviews of mobile commerce, we make a set of knowledge maps to show the future trend of mobile commerce and analyze visual results based on I-model. It is the first study to present the major clusters to reveal their associated intellectual bases and research fronts.
\end{abstract}

Keywords: mobile commerce; CiteSpace; knowledge mapping; I-Model

\section{Introduction}

With the rapid growth of wireless networks and smartphone, consumers have paid more attention to mobile commerce. The number of mobile users and the market for mobile technologies have grown enormously in the past few years [1]. The most famous mobile companies in the world and the number of their users are listed in Table 1. As the superpower nation, the total number of mobile users has exceeded 1.3 billion in China [2], which greatly drives the development of 5G communication technologies to maintain more and more mobile users for accessing the communication networks $[3,4]$. Globally, individuals tend to spend more time on their smartphones. The transactions via mobile devices had exceeded PC several fold. Of $\$ 150$ billion online spending in America, $80 \%$ is generated by mobile users. Mobile terminal is used as a good information carrier, with the features of convenience and immediacy [5]. The M-commerce environment has changed the daily life and working efficiency of humans but only two literature reviews about m-commerce were found, published in 2007 and $2010[6,7]$. With the advance of the One Belt One Road strategy and Internet+ strategy, there are many 
new features in m-commerce. To build the Silk Road, some risks of cross-border platforms in the context of m-commerce should be identified including how to harness the power of big data and cloud service platforms on mobile terminal to provide an intelligent decision service. More artificial intelligence should be introduced into $\mathrm{m}$-commerce for maximum business value. In addition, a unified mobile information platform should be built to speed up smart city construction. The social trend of mobile apps is obvious. The traditional consumer behavior pattern is the AIDMA model. AIDMA is one of the mature theoretical models in the field of consumer behavior, which was proposed by E.S. Lewis in 1898. According to this theory, consumers will go through attention, interest, desire, memory, action stages from receiving information to purchase. The SICAS model is proposed for the mobile internet digital era. It includes sense interest, interactive connect, communicate action share. It indicates that consumers pay more attention to participation and interactive. They are willing to share the process with the community [8]. Based on the new features of m-commerce. We analyzed the existing literature by CiteSpace, then put high-frequency vocabulary into the four sub-dimensions of I-model. The gap between theoretical research and reality is found. We added the new influence factor of $\mathrm{m}$-commerce adoption and extended the traditional model in the new context of reality. Some new problems and future trends in m-commerce are proposed.

Table 1. The famous mobile company in the world. Source: http://www.cww.net.cn/.

\begin{tabular}{cccc}
\hline Ranking & Operator & User/Million & Contry \\
\hline 1 & AT\&T & 129 & American \\
2 & China Mobile & 910.2 & China \\
3 & Verizon & 110.2 & American \\
4 & Communications & 61.73 & Japan \\
5 & NTT & 140 & Germany \\
6 & T-Mobile & 730.2 & British \\
7 & Vodafone & 40.2 & Japan \\
8 & SoftBank & 460.2 & Spain \\
9 & Telefonica/O2 & 180.6 & China \\
10 & China Unicom & 80.3 & Mexico \\
\hline
\end{tabular}

We collect the original data from the SSCI, CPCI-S, SCI-EXPANDED, CPCI-SSH database. The data covers 1130 articles which were published between 2000 and 2018. The article structure is organized as follows: first, a comprehensive summary of literature on mobile commerce and related work are presented; second, we provide an introduction of CiteSpace and I-model; third, we show how to collect data; fourth, we present the results analyzed by CiteSpace and make a deeper analysis; finally, we predict $\mathrm{m}$-commerce future trend by analyzing major clusters. We provide the main conclusions at the end of the paper.

\section{Literature Review and Related Work}

M-commerce is characterized by convenience and ubiquity. It is a commercial activity building on a variety of handheld terminals. The most common devices are mobile phones and palmtop. Mobile commerce derives from e-commerce. Constantinos Coursaris and Khaled Hassanein suggested that mobile commerce can be considered as a subset of e-commerce [9]. There are several factors that can play a major role in the success of $\mathrm{m}$-commerce. It can be distinguished in three categories. The first is security and trust. Second, personalization and localization. Last but not least, the user's convenience. Security and trust are the most crucial factors in the success of m-commerce [10]. Most of the mobile commerce market in European is composed of mobile payments, advertising and shopping services in the resent years. Varshney and Vetter presented a new point that m-commerce can be considered as four-level integrated framework: commerce applications, mobile middleware, wireless user infrastructure and wireless network infrastructure [11]. Mobility is the main feature of m-commerce 
applications. We can enjoy the online service without time and position restrictions. With the fast development of mobile devices, mobile commerce is simple to operate and cost-effective [12]. Mobile commerce is already used in diverse applications. It can offer service, such as payment, advertise, book the tickets, online shopping and real-time news. Based on previous literature, we attempt to summarize the classification of mobile commerce applications in terms of financial, devices, middleware and networks (see Table 2).

Table 2. The types of mobile commerce applications.

\begin{tabular}{lll}
\hline Class of Applications & Description & Examples \\
\hline Mobile financial applications & $\begin{array}{l}\text { Applications which is Banking, brokerage and } \\
\text { payments though mobile device. }\end{array}$ & E-Bank, brokerage, mobile payment. \\
\hline Mobile advertising & $\begin{array}{l}\text { Applications turning the network platform and } \\
\text { mobile device into a selling tool. }\end{array}$ & Mobile marketing \\
\hline Mobile inventory management & $\begin{array}{l}\text { Applications that concentrate on cutting down } \\
\text { the number of inventory by mobile inventory } \\
\text { management system. }\end{array}$ & $\begin{array}{l}\text { Location tracking of goods, boxes, } \\
\text { troops and people. }\end{array}$ \\
\hline Proactive service management & $\begin{array}{l}\text { Applications provide information and services } \\
\text { to users immediately. }\end{array}$ & Wearher forecast, stock information \\
\hline Wireless re-engineering & $\begin{array}{l}\text { Applications attemptting to enhance the quality } \\
\text { of services using wireless mobile infrastructure. }\end{array}$ & $\begin{array}{l}\text { Instant payments by insurance } \\
\text { companies. }\end{array}$ \\
\hline Mobile auction or reverse auction & $\begin{array}{l}\text { Applications allowing users to persuit good } \\
\text { and service in the form of auction. }\end{array}$ & E-bey. \\
\hline Mobile entertainment services and games & $\begin{array}{l}\text { Applications offering the entertainment to } \\
\text { mobile users. }\end{array}$ & Online vedio, music interactive games. \\
\hline Mobile office & $\begin{array}{l}\text { Applications attempting to provide the office } \\
\text { environment to users anywhere. }\end{array}$ & Vedio conference \\
\hline Mobile distance education & $\begin{array}{l}\text { Applications provide education to mobile users } \\
\text { without the limitations of distance. }\end{array}$ & Online class \\
\hline Wireless data cente & $\begin{array}{l}\text { Applications provide data storage services to } \\
\text { mobile users for decision support. }\end{array}$ & Baidu cloud storage \\
\hline
\end{tabular}

E.W.T. Ngai reviewed the literature between 2000 and 2003 on m-commerce using a suitable classification scheme to identify the future research directions. The articles are classified based on a scheme that consists of five distinct categories: $\mathrm{m}$-commerce theory and research, wireless network infrastructure, mobile middleware, wireless user infrastructure and $\mathrm{m}$-commerce applications and cases [6]. Wu executed a comprehensive review on papers published between 2000 and 2009 about consumer behaviour in mobile commerce. The papers can be classified into three theme: consumer acceptance, loyalty and continuance. Based on the analysis, the paper gave suggestions for the future study [7]. Carolina contributed to integrating TAM and diffusion theory to assess advanced mobile services acceptance. Gerpott made a meta-analysis on mobile Internet usage intensity levels and potential determinants of respective usage behavior [13]. Sonia analysed which factors impact firms' perceived performance in mobile commerce by adding customer value and the relationship marketing for the firm [14]. Li analysed literature from 1994 to 2009 on key technologies of 3G mobile communication system by CiteSpace and Derwent Innovation Index. The paper illustrated the key technologies evolution [15]. Wong made a review on mobile-assisted seamless learning. The paper use ten dimensions that characterize MSL to fill research gaps in the area [16]. Saura made a literature review of digital marketing strategies based on the E-Business Model and stated future directions [17].

Although a lot of literature is available on m-commerce, the extant literature has paid little attention to the future trend of $\mathrm{m}$-commerce value by using CiteSpace and I-model. In addition, there is no literature review on mobile commerce in recent years. With the wide application of artificial intelligence and big data, the main objective of this research is to identify the main technology and models to improve customer satisfaction and adoption behavior in the background of the new era. Data mining based on CiteSpace and four dimensions of the I-Modelare combined together to explore the knowledge structure, development and the future trend of mobile commerce. 


\section{Conceptual Framework and Research Questions}

\subsection{CiteSpace}

Bibliometrics is the most common statistical method to analyze literature. The main categories of bibliometrics are the authors, keywords, references, journals and the trends. Visualized analysis of bibliometrics can be proceeded under the computer technology. As an important branch, visual analysis software has achieved significant progress. Mapping knowledge as a useful method has been widely applied in revealing the trend of some fields [18]. Ma emphasised that visualized analysis based on co-citation can provide more usefull information. It could help researchers find the recent trend in a special field and forecast the future direction. We presents the development of mobile commerce by using CiteSpace which supports by Java application [19]. CiteSpace was identified as a bibliometric analysis tool, which could generate visual maps in order to discover trends in a field. It is designed for finding turning point in the evolution of a pecific domain. It provides a useful literature analysis tool to identify fast-growing areas, find collaborative relationships between institution and country, apply a network into clusters, labell clusters from citing articles keywords and so on. In building the network view, three types of views-cluster view, timeline view and timezone view can be applied to analyze different results including knowledge structure and evolution of trends, respectively. The preferred data source for CiteSpace is the Web of Science [20]. CiteSpace includes nodes and links. Different nodes represent different elements in a visualization knowledge map such as country, reference, institution and author. Links between nodes should be considered as strength of relationships. The size of nodes indicates the aggregate co-occurrence frequency of an element, whereas the color of the ring in a map show the co-occurrence time slices of this item. The nodes with a purple color represents high centrality which usually perceived as critica turning points in a field. Centrality which measures the ability of a node connecting with other nodes. In other words, a node with a high centrality (range from 0 to 1) illustrates that the node acts as a key point linking and the primary topics in a network. We can solve the problem by using citespace, for example, which articles are important turning point in mobile conmmerce research field. Which subject are mainstream. How has the research front evolve.

\subsection{I-Model}

The information model developed by Zhang and Benjamin is one of the most important frameworks for classifying commerce activities. It included four dimensions: information, technology, people and organization/society based on commerce's attributes and disciplines. Information derived from library science and information science, technology mainly consists of computer science and engineering, people are about psychologies, sociologists and cultural anthropologists, while organization covers many social sciences [21]. I-Modelas a theoretical framework can reveal some usefull results from four dimensions that were not revealed before and point out potential opportunities [22]. In my paper, information has special meanings and transfer function, we focus on the information that has social purposes [23]. People are the driving force of the mobile commerce and mobile application, it may be consumers or sellers. People are key factor in mobile commerce because they provide the information and make the different results through information interaction [24]. Technology is the basic of mobile commerce covers wireless network, mobile middleware, database, applications, mobile handheld device and services [25]. The last step is organization information and produce social value. This process involves policies, management, strategies, operation and cultures. We use I-Modelto provide a theoretical framework of mobile commerce and reveal research trends. The I-Modelprovide a method to analyze the evolution of a specific field and fill a gap in the current research area [26]. Zhao shows that crowdsourcing facilitate the connectivity and collaboration of people, organizations and societies in information systems. The paper analyzed the evaluation on crowdsourcing research and indicated the future direction based on I-mode [27]. Cui investigated the intellectual structure, development and evolution of social commerce based on I-Model [28]. We think there is room for researchers combine two or more dimensions of the I-Modelto improve theoretical 
framework of mobile commercial parttern. Therefore, we apply the I-Modelin our visualized analysis to provide a more complete research framework and point out future research trend.

\subsection{Problem Statement}

With the advance of One Belt One Road strategy and Internet+ strategy, there are many new features in m-commerce. How to harness the power of big data and cloud service platform on mobile terminal to provide intelligent decision service. More and more artificial intelligence should be introduced into m-commerce for maximum business value. In addition, a unified mobile information platform should be built to speed up the smart city construction. The social trend of mobile apps is obvious. The main objective of this research is to identify the main technology and models to improve customer satisfaction and adoption behavior in the background of the new era. Data mining based on CiteSpace and four dimensions of the I-Modelare combined together to explore the knowledge structure, development and the future trend of mobile commerce.

\section{Methodology}

This paper used CiteSpace and Java to undertake a visual analysis of mobile commerce. We collect data from 2007 to 2018 based on the Web of Science database. Because a lot of high-quality papers and influential articles are collected in the database and it is the preferred database website for CiteSpace [29]. In order to collect the full records of samples and eliminate useless information. First, we chose Web of Science Core Collection. Secondly, selecting index of Science Citation Index Expanded (SCI-EXPANDED), Social Sciences Citation Index (SSCI), Conference Proceedings Citation Index-Science (CPCI-S) and Conference Proceedings Citation Index-Social Science and Humanities (CPCI-SSH) as target set. Thirdly, we set 2007-2018 as the time period due to more and more people enjoy the convenience from smart phones and mobile payment during this period. The rapid development of Internet of Things technologies and 5G wireless technologies will bring new opportunities for mobile commerce. To make sure the completeness of sample collection. We search the term of "Mobile commerce" or "M-commerce", then 1130 articles relate to mobile commerce was found. We put the articles into citespace and discover the important information of mobile commerce (Table 3).

Table 3. Summary of searching details.

\begin{tabular}{ll}
\hline Source Website & Web of Science \\
\hline Database & SCI-EXPANDED; SSCI; CPCI-S; CPCI-SSH \\
Years & January 2007-October 2018 \\
Searching term & "Mobile commerce" or "M-commerce" \\
Sample size & 1130 \\
Reference & 25,502 \\
\hline
\end{tabular}

\section{Analysis and Results}

We found 1130 articles and downloaded in October 2018. We have supplemented the number of literature up until 2018 in Figure 1. A large number of publications were published from 2007 to 2009. Because electronic commerce and mobile devices had rapid development at this time. Therefore, more and more researchers pay attention to the hot topic, as a new research field, a large amount of articles about mobile commerce emerged. In general, the number of publications has reached a summit in 2008 with he rapid development of wireless communication technology and mobile users [30]. Then there was a slight decrease from 2009 as the explosion of global financial crisis and the research heat decline. On the other hand, because of technological and equipment limits. There was steady increases after 2012. Due to the rapid development of smartphone and mobile APP, which lead to a better mobile network environment. Therefore, it can be considered that the research of mobile commerce is in the rapid development period. 


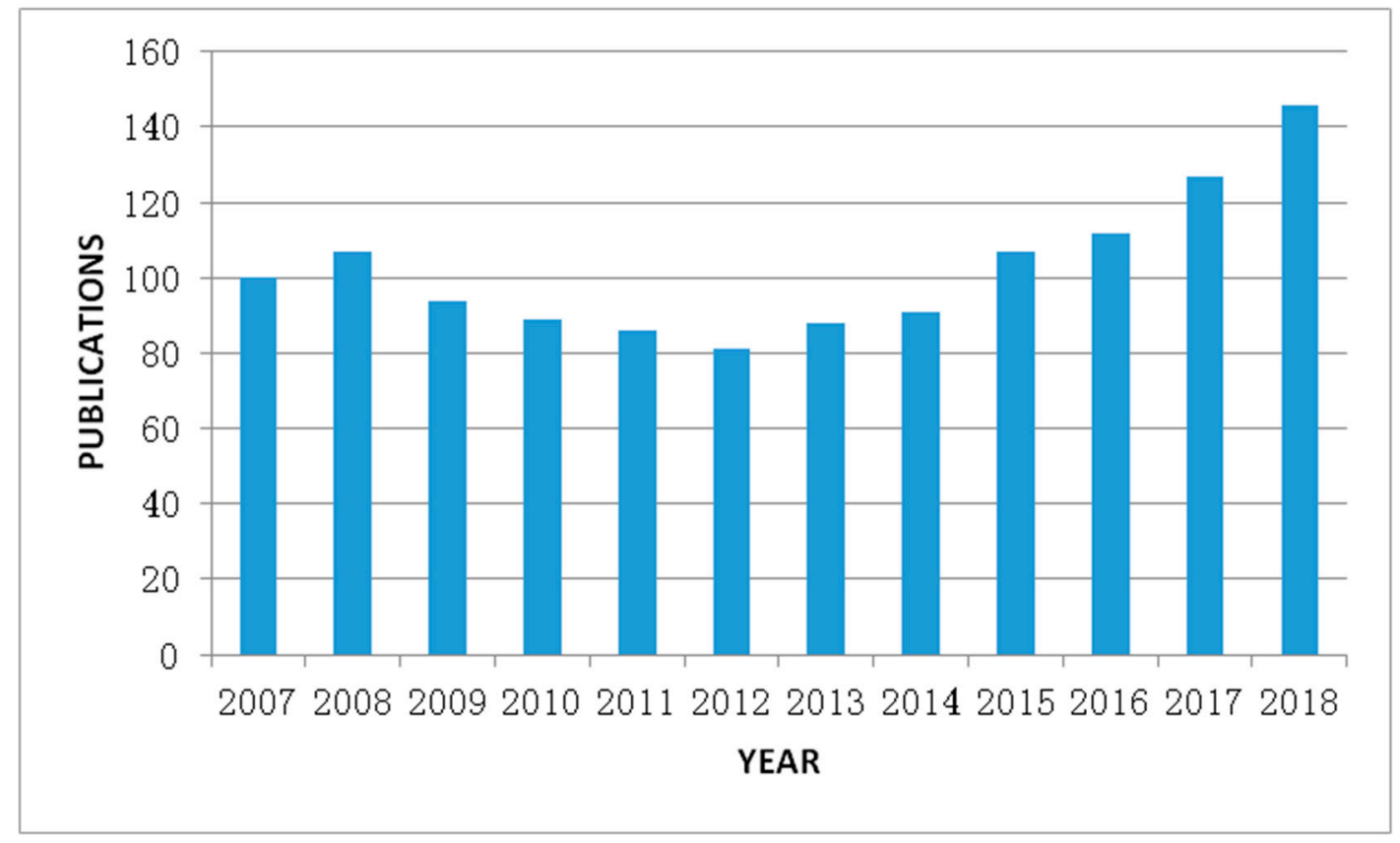

Figure 1. Number of publications.

\subsection{Mapping and Analysis on Author and Citied Authors}

We selected the top 10 most productive authors from the output of CiteSpace. Then we serach their articles in the database to find their main focuses (see Table 4). Most of them pay attention to the field of customer satisfaction and mobile commerce application, such as mobile technology acceptance model, mobile payment, mobile learning. It provided guidance for our research. We listed the top 10 most productive authors and their main focuses in Table 4. The map of authors network is presented in Figure 2, in the map, blue is representative of earlier articles, green is for middle years whereas yellow is viewed as recent articles. Since mobile commerce appears later than electronic commerce, the articles are fewer than e-commerce. Meanwhile, we have selected the articles from several database, some publications about mobile commerce beyond our database are not be mentioned. Therefore, we mined the information about top 10 most cited authors.

Table 4. Top 10 most productive authors.

\begin{tabular}{lll}
\hline Author & Publications & Main Focuses \\
\hline Ooi K.B. & 16 & mobile payment, trust, mobile technology acceptance model \\
\hline Lu Y.B. & 9 & mobile brokerage service \\
\hline Chong A.Y.L. & 9 & technology acceptance model, customer satisfaction analysis \\
\hline Min Q.F. & 7 & mobile system usability, information communication media \\
\hline Tan G.W.H. & 7 & mobile learning, mobile credit card, hybrid structural equation modeling \\
\hline Zhou T. & 6 & m-commerce user acceptance behavior, technology acceptance model \\
\hline Xin C. & 6 & m-commerce application, business model, mobile payment, m-commerce service \\
\hline Morosan C. & 6 & interactive mobile technologies \\
\hline Chang S.E. & 5 & mobile devices, mobile financial services \\
\hline Zhang R.T. & 5 & mobile commerce identity, authentication mechanism \\
\hline
\end{tabular}




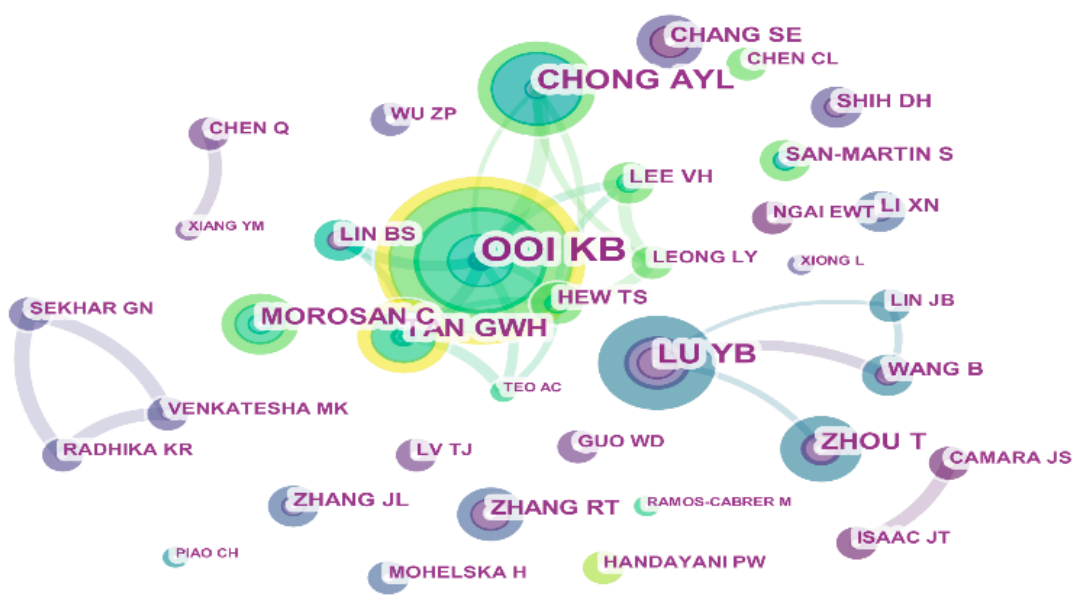

Figure 2. Map of authors co-citation.

We find the most influential authors by analyzing the results and identify the research trajectories of mobile commerce over time. The top 10 cited authors with frequency and centrality are listed in Table 5. Then we show the knowledge map of cited authors in Figure 3. The clustering analysis method we applied timezone which is used to describe the trends and interactions of themes over time. Centrality represents relationship strength between nodes. Nodes with purple means that the authors have significant influence in the evolution of mobile commerce. In order to find the knowledge structure, we select every 2 years as a time slice [31]. There are three key authors in this research field which are Venkatesh, Davis and Fornell. Venkatesh mainly focus on mobile commerce usability. The paper from Venkatesh showed that customers' interface experience can create good customer sensory satisfation based on empirical analysis. The paper from Davis showed more concern for consumer behavior and technology acceptance model (TAM) technique which has been widely applied in mobile commerce. Fornell have concentrated on mbile commerce application and consunmer trust. On further review of the literature, we found that the mobile commerce usability is the first hot topic followed by consumer behavior. Now more and more people pay attention to mobile commerce application. We selected authors with high citations in resent year. There are three different nodes distributed at the end of Figure 3 termed as "Zhang LY, Wei TT, Podsakoff PM". Intracking their citation history. Their research focuses on mobile commerce application and mobile commerce technology.

Table 5. Top 10 most cited authors.

\begin{tabular}{ccc}
\hline Author & Frequency & Centrality \\
\hline Davis F.D. & 243 & 0.13 \\
Venkatesh V. & 237 & 0.06 \\
Fornell C. & 158 & 0.07 \\
Gefen D. & 142 & 0.14 \\
Fishbein M. & 123 & 0.07 \\
Wu J.H. & 121 & 0.07 \\
Hair J.F. & 109 & 0.04 \\
Rogers E.M. & 106 & 0.07 \\
Bagozzi R.P. & 92 & 0.06 \\
Ajzen I. & 91 & 0.02 \\
\hline
\end{tabular}




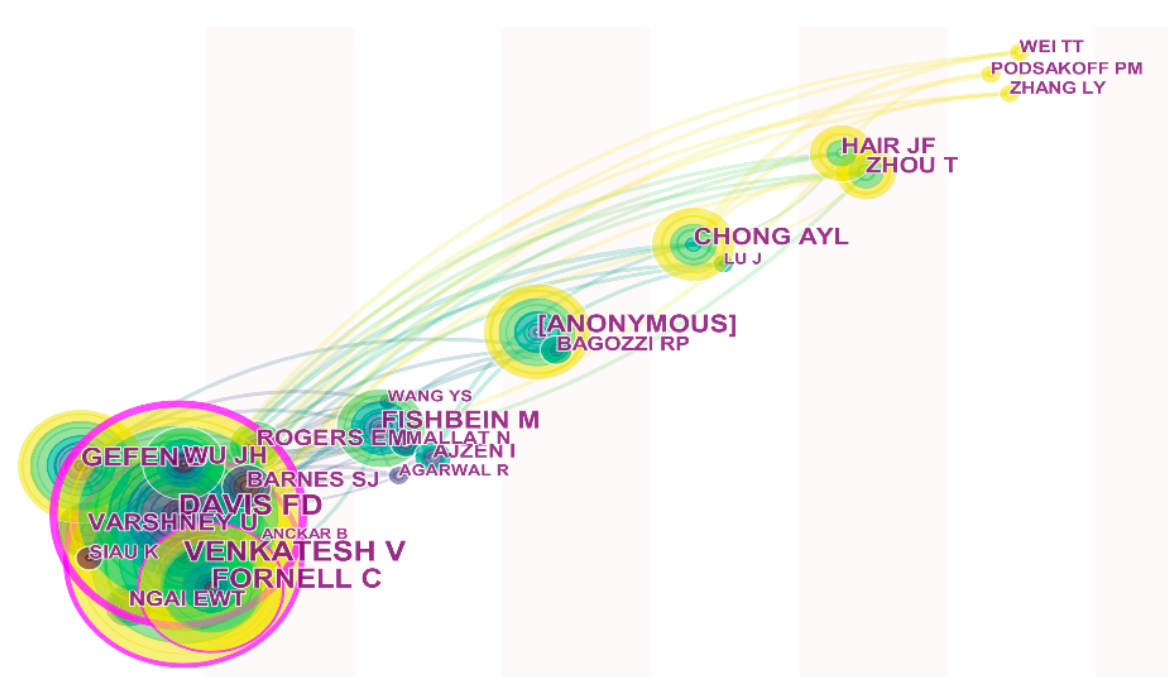

Figure 3. Map of cited authors timezone view.

\subsection{Mapping and Analysis on Institutions and Countries}

We will easily discover the leading research institutes of mobile commerce through institution visual analysis. According to our database from Table 6, Huazhong Univ Sci \& Technol is the most productive academic institution with 24 articles and 0.02 centrality. Huazhong Univ Sci \& Technol has much cooperation with other institutions, such as Univ Texas Pan Amer, Hangzhou Dianzi Univ and Wuhan Univ Sci \&Technol. In addition, it focused on cusumer trust. Univ Tunku Abdul Rahman is another influential university. It paid attention to the technology acceptance model and customer satisfaction analysis. The cooperation network of analysis result is shown in Figure 4.

The result of top 10 productive countries and territories from the visual software are displayed in Table 7. The cooperation network of analysis result is shown in Figure 5. There are 523 publications from China which is nearly one third of the total 1130 papers. This result showed that China is a productive country in the fields of mobile commerce. However, USA with the highest centrality had a lot of influence on mobile commerce. Because it had frequent cooperation with other countries and made great achievements in mobile commerce. In addition, USA is the first country to have a smartphone that's technically superior in every aspect and mobile commerce is applied more widely. Further, we found that the USA had a strong citation burst in 2009 and 2016 though the burst detection analysis. In this sense, with the rapid growth of wireless networks and the popularization of mobile devices, mobile commerce is growing rapidly in China. But the US is more mature in mobile technology and application.

Table 6. Top 10 productive institutions

\begin{tabular}{ccc}
\hline Institution & Publications & Centrality \\
\hline Huazhong Univ Sci \& Technol & 24 & 0.02 \\
Univ Tunku Abdul Rahman & 20 & 0.04 \\
Natl Chung Hsing Univ & 17 & 0.01 \\
Beijing Univ Posts \& Telecommun & 15 & 0 \\
Beijing Jiaotong Univ & 14 & 0 \\
Dalian Univ Technol & 13 & 0 \\
Natl Chiao Tung Univ & 12 & 0 \\
Natl Sun Yat Sen Univ & 11 & 0.01 \\
Hong Kong Polytech Univ & 11 & 0.03 \\
Wuhan Univ & 11 & 0 \\
\hline
\end{tabular}




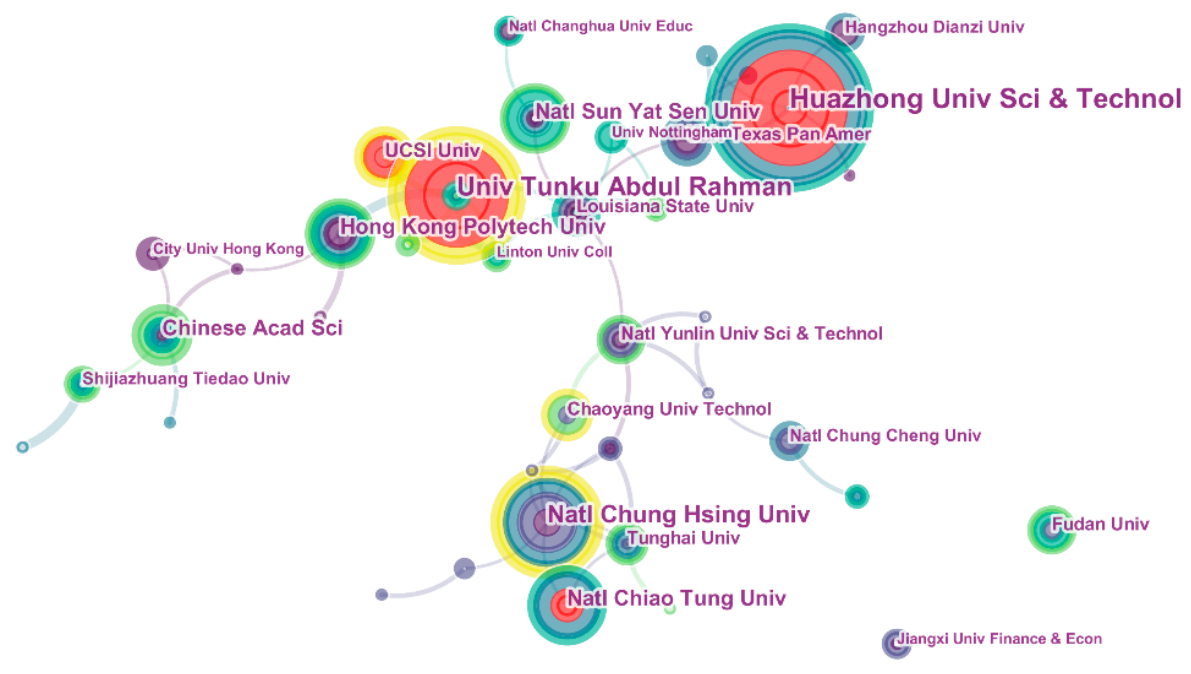

Figure 4. Map of institutions.

Table 7. Top 10 productive countries and territories.

\begin{tabular}{ccc}
\hline Country/ Territory & Publications & Centrality \\
\hline People R China & 348 & 0.12 \\
Taiwan & 175 & 0.07 \\
USA & 171 & 0.54 \\
India & 77 & 0.01 \\
Malaysia & 58 & 0.07 \\
South Korea & 51 & 0.09 \\
Spain & 39 & 0.25 \\
England & 37 & 0.55 \\
Canada & 31 & 0.18 \\
Germany & 29 & 0.15 \\
\hline
\end{tabular}

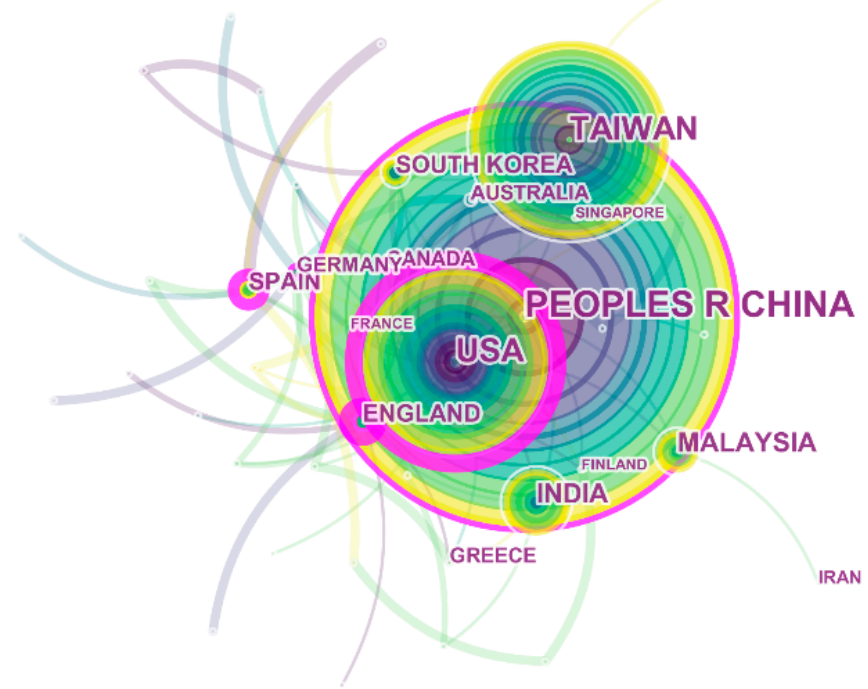

Figure 5. Map of countries. 


\subsection{Mapping and Analysis on References}

We can discover the highly cited papers and main contribution on mobile commerce through map of references co-citation. In Figure 6, each node represents one references. The colour of blue represents the earliest years, the colour of green represent mid-range years, the colour of yellow represents late years. Table 8 provided the top 10 most cited references and frequency. Paper from Wu J.H. is the most cited reference. It focused on mobile commerce acceptance and extended technology acceptance model. It put perceived risk and cost into the TAM and raised innovation diffusion theory. The second most frequently co-cited article is from Wei T.T., they examine the factors that affect the mobile user's behavior. It proved usefulness, simple to use, social value, cost and trust are the key factors [32]. The article from Ngai EWT is another influential study in mobile commerce. This paper is a literature review about $\mathrm{m}$-commerce. Future research direction is discussed in the article by classification scheme. Venkatesh V. discussed that customers' experience via the interface satisfy their sensory [33]. Chong A.Y.L. extended the TAM and DOI model as well as described the new variables such as trust, multi-service, educational level and gender [34]. Kim H.W. provided the value perspective for researcher to understand mobile Internet and communication technology. Li Y.M. researched how aesthetics of mobile website design impact on mobile commerce user trust [35]. Zhang L.Y. indicated the relationship between culture and commerce adoption by using structural equation modeling [36]. Kim C. try to design different types of mobile payment systems for variety personalities of mobile payment users, on this basis, future research in mobile payment have been given. Barnes S.J. explored how to increase some values at each step of mobile commerce. The paper analyzed the key players and technologies of the $\mathrm{m}$-commerce value chain and provided a basic study of business strategy. The research question and method for each reference are described in Table 8.

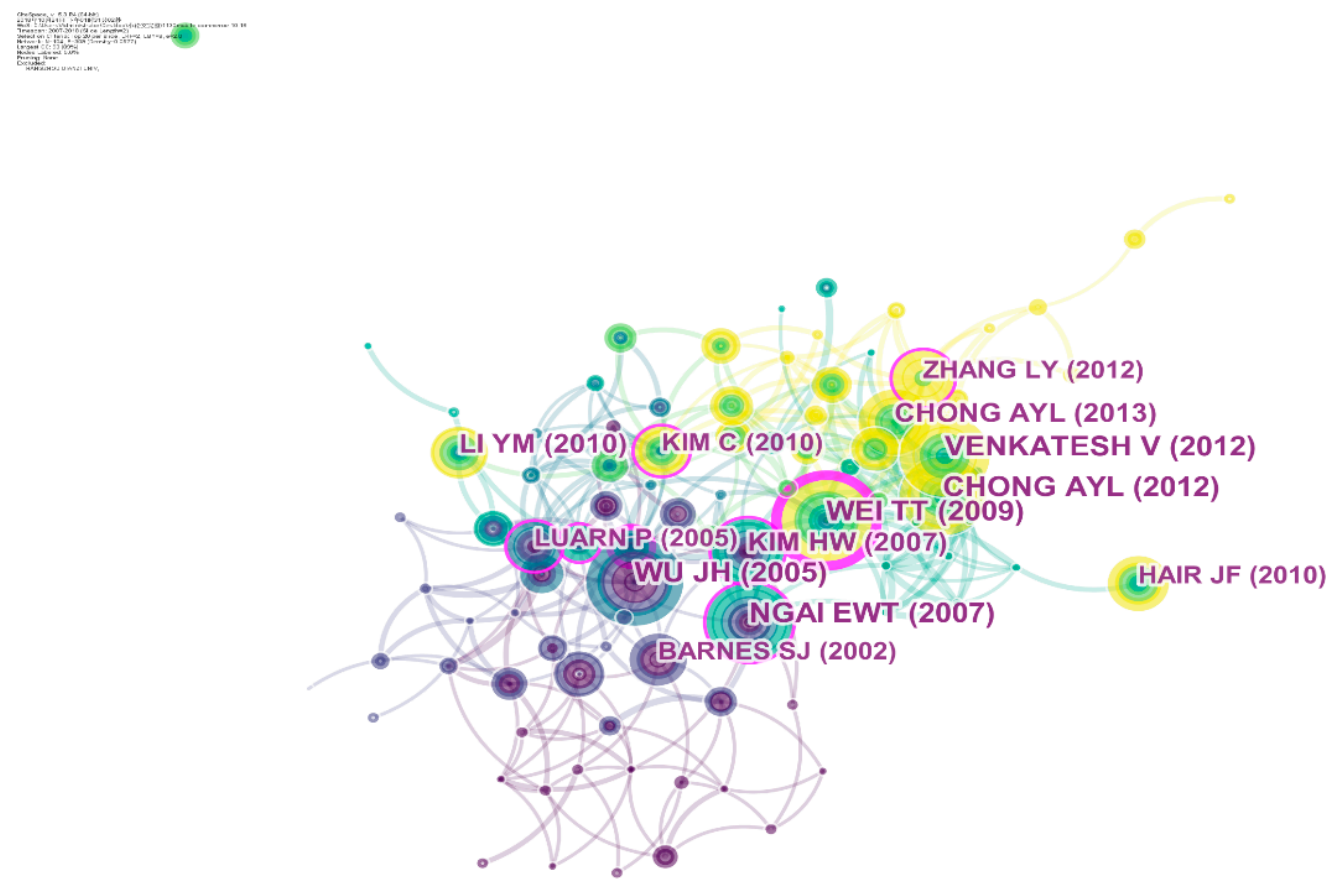

Figure 6. Map of references co-citation. 
Table 8. Top 10 most cited references.

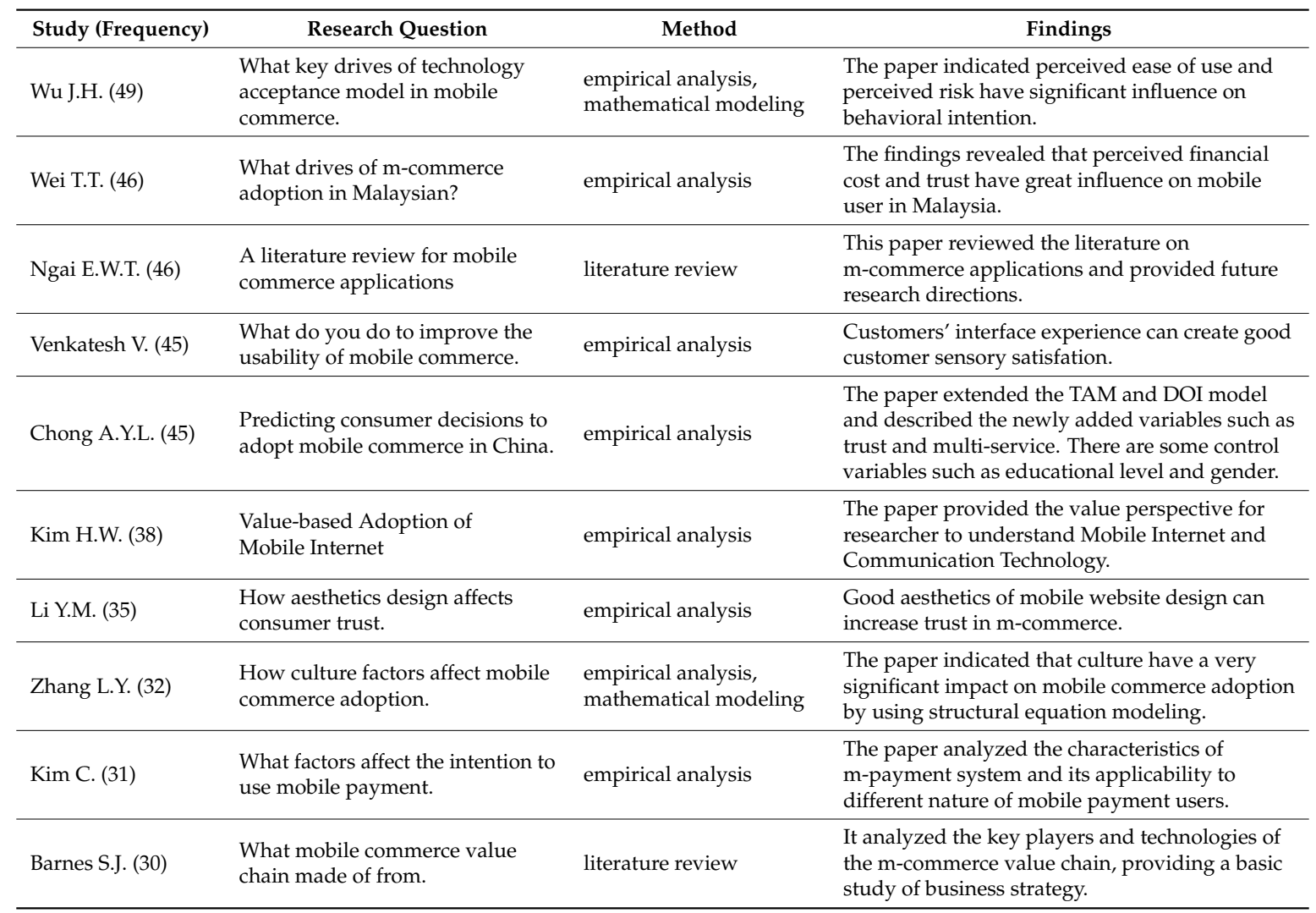

In summary, 8 out of 10 top cited studies use the empirical analysis method and 2 of them adopt the method combined with empirical analysis and mathematical model. This information indicates the main method in mobile commerce is empirical analysis. In addition, 5 out of 10 top cited references is about $\mathrm{m}$-commerce adoption. In these articles, perceived risk, perceived financial cost, variety of services and culture has positive influence on behavioral intention, control variables such as educational level and gender will also influence the final results. 3 of them extended technology acceptance model. 2 out of 10 top cited studies are about consumer behavior, they investigated the influence of user interface and design aesthetics on customer trust. Two studies introduced m-commerce applications and value chain by the way of literature review which provide a theoretical framework of mobile commerce research. Paper from Wu J.H. cited the most because this study first extended technology acceptance model (TAM), he added the new variable such as perceived risk and cost into the TAM and found out the key factors which influence user mobile commerce acceptance.

We show a reference network in Figure 6 to display key turning points. Besides the important view we have proposted above, we have found three important tuning points with purple rings. A study from Wei T.T. was the earliest research which tested cost and trust are positive with mobile users by the way of empirical analysis. Whereas Kim C. analyzed the characteristics of m-payment system and its applicability to different personality of mobile payment users. Zhang L.Y. put cultural factor into the model and analyzed the influence on mobile commerce adoption by using structural equation model. Besides, the node with yellow color stands for the latest researches which may help us predict future trend in this area.

\subsection{Mapping and Analysis on Journals}

We usually use Journal co-citation network analysis to reveal which journals represent the frontier research of mobile commerce. We show the top 10 most cited journals in Table 9 . The scope of these journals are focused on electronic commerce and information systems. We can get the information 
from journal co-citation network shown in Figure 7, "Information Systems Research", "MIS Quarterly" and "Computers in Human Behavior" played important roles in the evolution of mobile commerce, whereas "MIS Quarterly", "Information and Management" have high cited frequency. "MIS Quarterly" have most contribution to mobile commerce with a frequency of 371 articles. "Information and Management" and "Communications of the ACM" follow with 331 and 313 articles, respectively.

Table 9. Top 10 most cited journals.

\begin{tabular}{|c|c|c|}
\hline Journal & Frequency & Scope \\
\hline MIS Quarterly & 371 & $\begin{array}{l}\text { Studies about integrated management, the resources management, } \\
\text { management science and engineering and economics of IT. }\end{array}$ \\
\hline Information and Management & 331 & $\begin{array}{l}\text { The journal serves researchers in the information science and } \\
\text { computer science field, computer software, machine translation and } \\
\text { natural language understanding are its subjects. }\end{array}$ \\
\hline Communications of the ACM & 313 & $\begin{array}{l}\text { The main research direction of ACM involved engineering } \\
\text { technology and theoretical method. }\end{array}$ \\
\hline Decision Support Systems & 309 & $\begin{array}{l}\text { Engineering technology; Computer information system; DSS } \\
\text { Interfaces; artificial intelligence }\end{array}$ \\
\hline Information Systems Research & 278 & $\begin{array}{l}\text { The journal covers many areas related to management, information } \\
\text { science and library science }\end{array}$ \\
\hline Computers in Human Behavior & 258 & $\begin{array}{l}\text { This Journal dedicated to computer synthesis and frontier research } \\
\text { from psychological perspective. }\end{array}$ \\
\hline Management Science & 251 & $\begin{array}{l}\text { The journal covers all aspects of management related to plan, } \\
\text { process, organization, strategy and culture. }\end{array}$ \\
\hline Journal of Marketing Research & 241 & $\begin{array}{l}\text { Empirical research that analyze consumers behavior. Develop sales } \\
\text { and marketing strategies depending on the type of consumer. }\end{array}$ \\
\hline $\begin{array}{l}\text { Journal of the Academy of } \\
\text { Marketing Science }\end{array}$ & 228 & $\begin{array}{l}\text { The journal devoted to proposing new methodologies of marketing } \\
\text { and making up the gap between theory research and practice in the } \\
\text { marketing field. }\end{array}$ \\
\hline $\begin{array}{l}\text { Electronic Commerce Research } \\
\text { and Applications }\end{array}$ & 223 & $\begin{array}{l}\text { The journal aims to create the knowledge, method, problem and } \\
\text { applications for the development of electronic commerce. }\end{array}$ \\
\hline
\end{tabular}

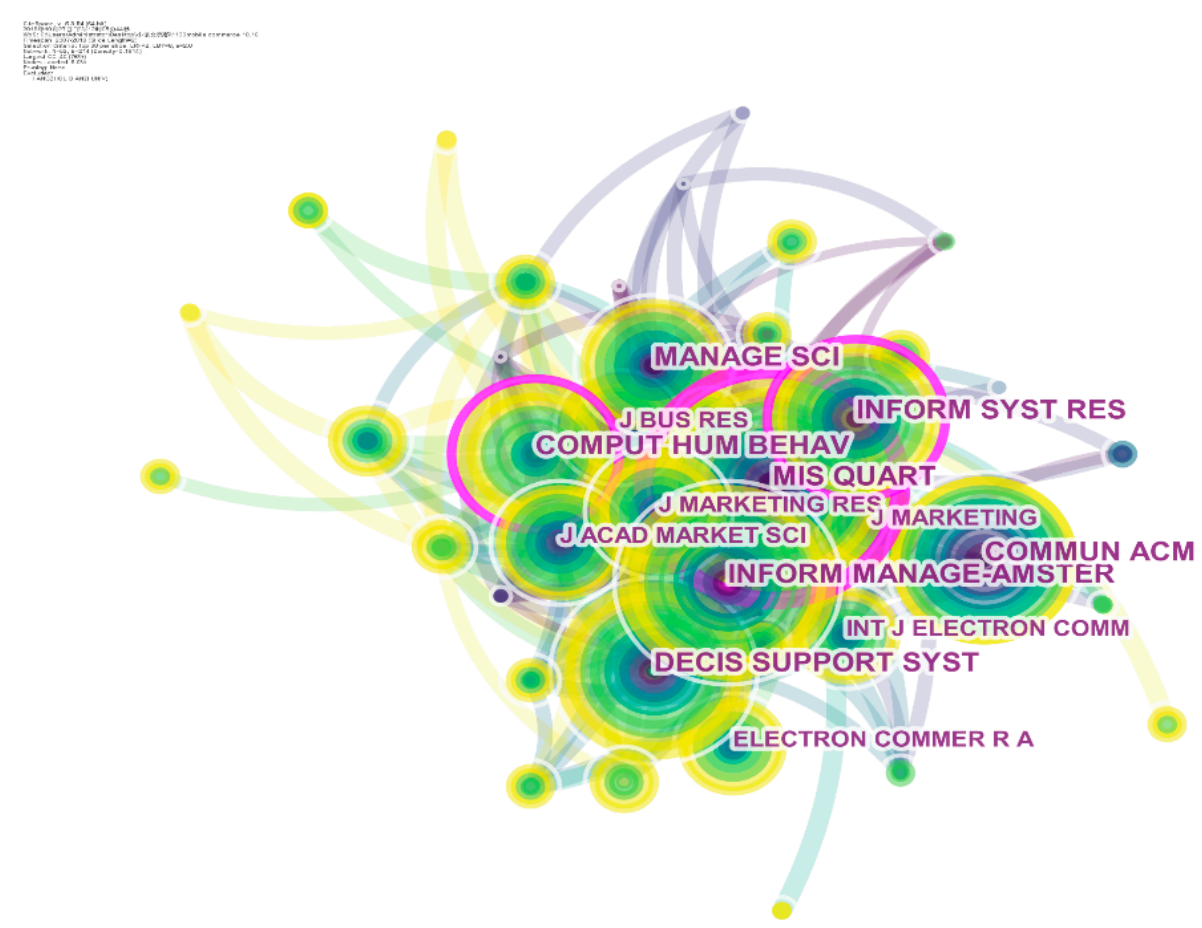

Figure 7. Map of journal co-citation. 


\subsection{Mapping and Analysis on Keywords}

We have displayed a keyword network in Figure 8 to show popular research topics. In addition. Table 10 listed the keyword according to the frequency, year and centrality. As can be seen, keywords with high centrality include information technology, adoption, technology acceptance model, trust, internet. Among them, TAM is a research model widely used in consumer acceptance $[37,38]$. Many articles about m-commerce consumer acceptance extended TAM from many perspectives, such as cross-cutural, mobile shopping application, quality of the service and so on $[39,40]$. Based on the above, we can draw a conclusion that technology and mobile consumer behavior become hot research topic due to the rapid development of wireless Internet technology and huge mobile user market. In order to have a preliminary understanding of evolutions among research topics, popular topics in different years are presented in Table 10. We selected the keywords with strongest citation bursts. Citation bursts means the value of a variable changed greatly over a short period. They are used to find research topic in a a specific period. As shown in the Table 11, the time when it first appeared are presented, the topics first appeared in 2007 included mobile-user, payment-system, privacy, mobile commerce value chain and so on, this topics about mobile device and technology continue for a long time. Some of the research topics are identified as new trend in mobile commerce due to continue until 2018, such as customer satisfaction, O2O, m-commerce adoption, cross-border e-commerce, word of mouth, continuance intention and intelligent decision-making.

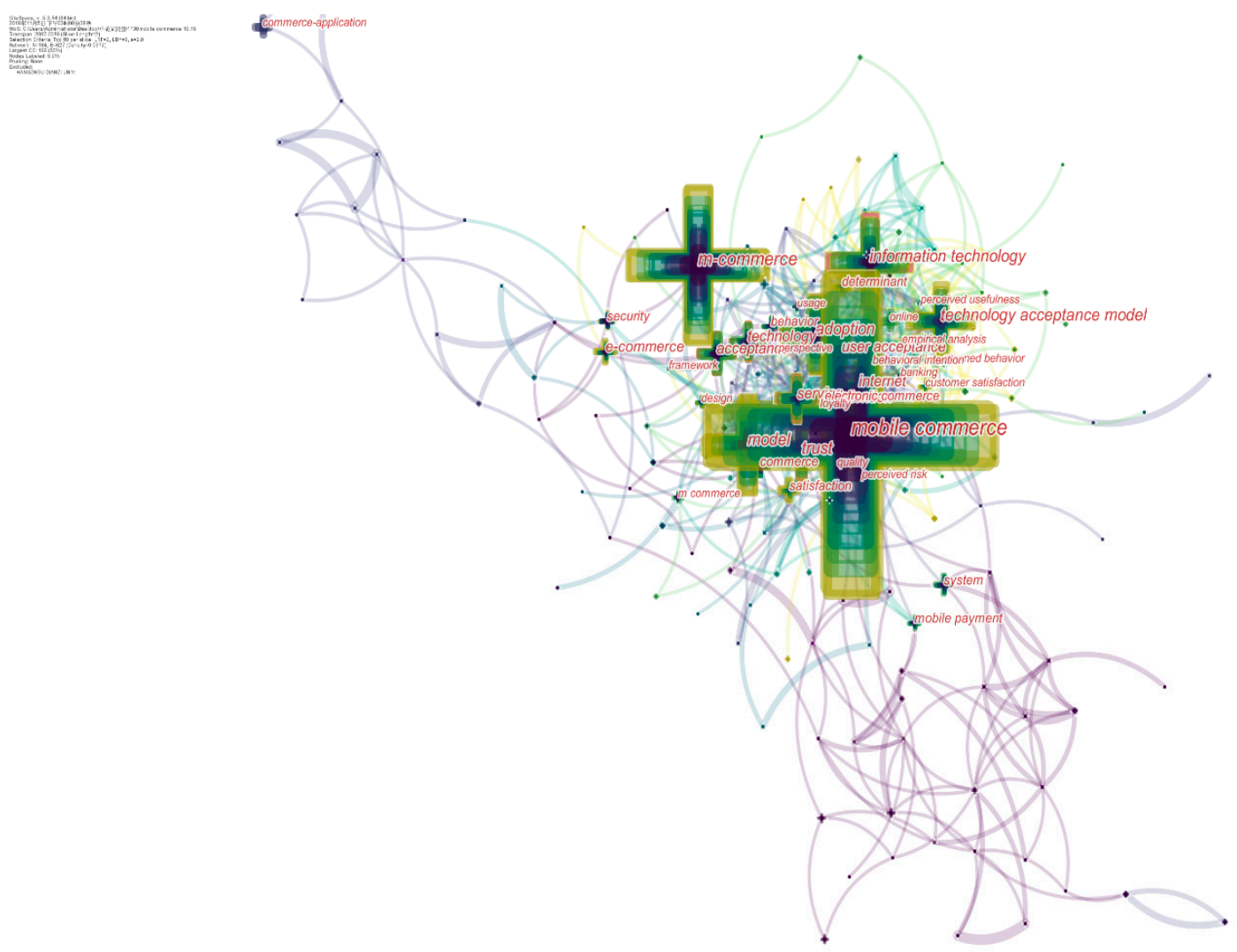

Figure 8. Popular research topics. 
Table 10. Main research topics by year.

\begin{tabular}{|c|c|c|c|c|c|c|c|}
\hline Year & Keyword & Centrality & Frequency & Year & Keyword & Centrality & Frequency \\
\hline 2007 & Information technology & 0.18 & 136 & 2009 & Online & 0.03 & 31 \\
\hline 2007 & Adoption & 0.07 & 121 & 2013 & Customer satisfaction & 0.02 & 30 \\
\hline 2007 & TAM & 0.08 & 110 & 2011 & Behavioral intention & 0.04 & 27 \\
\hline 2007 & Trust & 0.17 & 94 & 2011 & Planned behavior & 0.01 & 27 \\
\hline 2007 & Internet & 0.07 & 84 & 2009 & Loyalty & 0.03 & 26 \\
\hline 2007 & User acceptance & 0.13 & 80 & 2011 & Perceived risk & 0.04 & 25 \\
\hline 2007 & Service & 0.13 & 80 & 2009 & Application & 0 & 25 \\
\hline 2007 & Eechnology & 0.14 & 77 & 2009 & Framework & 0 & 25 \\
\hline 2007 & Acceptance & 0.12 & 74 & 2007 & quality & 0.01 & 24 \\
\hline 2007 & e-commerce & 0.01 & 62 & 2009 & perspective & 0 & 23 \\
\hline 2009 & intention & 0.08 & 58 & 2013 & empirical analysis & 0.01 & 23 \\
\hline 2009 & Determinant & 0.07 & 52 & 2009 & Perceived usefulness & 0 & 22 \\
\hline 2007 & Commerce & 0.06 & 49 & 2009 & Usage & 0.01 & 21 \\
\hline 2011 & Satisfaction & 0.06 & 46 & 2007 & Information system & 0 & 19 \\
\hline 2007 & System & 0.03 & 46 & 2015 & Service quality & 0 & 18 \\
\hline 2007 & Behavior & 0.03 & 43 & 2007 & Technology adoption & 0.1 & 18 \\
\hline 2009 & Design & 0.09 & 42 & 2007 & Commerce-system & 0.01 & 16 \\
\hline 2007 & Security & 0.09 & 41 & 2007 & Performance & 0.04 & 16 \\
\hline 2007 & Payment & 0.04 & 38 & 2007 & Mobile & 0.02 & 15 \\
\hline
\end{tabular}

Table 11. Top 40 keywords with strongest citation bursts.

\begin{tabular}{lccclccc}
\hline Keywords & Strength & Begin & End & Keywords & Strength & Begin & End \\
\hline Mobile-user & 6.35 & 2007 & 2008 & Structual equation modelling & 3.72 & 2013 & 2018 \\
Payment-system & 4.75 & 2007 & 2008 & Intelligent decision-making & 4.79 & 2013 & 2014 \\
Privacy & 4.24 & 2007 & 2010 & SVM & 4.51 & 2014 & 2018 \\
Mobile commerce value & 2.63 & 2007 & 2008 & Perceived usefulness & 3.04 & 2013 & 2016 \\
Value chain & 3.61 & 2007 & 2009 & Social commerce & 3.42 & 2015 & 2018 \\
Business-model & 4.95 & 2007 & 2010 & Customer satisfaction & 6.39 & 2014 & 2018 \\
Communication-technology & 4.76 & 2007 & 2008 & Behavioral intention & 6.19 & 2015 & 2018 \\
Mobile internet & 2.63 & 2007 & 2008 & m-commerce adoption & 5.31 & 2015 & 2018 \\
Mobile device & 3.88 & 2007 & 2010 & Laction based service & 2.93 & 2015 & 2016 \\
RFID & 2.82 & 2007 & 2010 & Mobile shopping & 3.92 & 2015 & 2016 \\
Mobile marketing & 2.59 & 2009 & 2010 & Service quality & 5.97 & 2015 & 2018 \\
Mobile agent & 3.63 & 2009 & 2010 & O2O & 3.42 & 2015 & 2018 \\
Web service & 2.59 & 2011 & 2012 & Neural network & 3.66 & 2015 & 2018 \\
Mobile advertising & 2.80 & 2011 & 2012 & Word of mouth & 4.06 & 2015 & 2018 \\
Data mining & 2.81 & 2011 & 2012 & Neural network approach & 3.42 & 2015 & 2016 \\
Social influence & 3.37 & 2011 & 2012 & Cross-border e-commerce & 5.11 & 2016 & 2018 \\
Empirical analysis & 3.88 & 2013 & 2018 & Mobile-app & 2.93 & 2015 & 2018 \\
Information system & 3.18 & 2013 & 2014 & Cloud-computing & 3.92 & 2015 & 2016 \\
Wireless communication & 4.26 & 2013 & 2014 & Personal-innovativeness & 4.97 & 2015 & 2018 \\
\hline
\end{tabular}

We show the evolutionary process about mobile commerce by analyzing keywords Co-citations. In Figure 9, 6 co-citation clusters are presented in a timeline view. The timeline is segmented into 4 sections. Different colors indicate chronological order, blue represents the earliest time and yellow represents the present. The colour range from blue, through green to yellow show evolution of time. From the Figure 9, keywords are divided into 6 clusters, they are Cluster ID\#0 mobile commerce consumer, Cluster ID\#1 sms advertising, Cluster ID\#2 m-banking service, Cluster ID\#3 mobile technologies, Cluster ID\#4 ubiquitous service-oriented design, Cluster ID\#5 mobile marketing research respectively. 


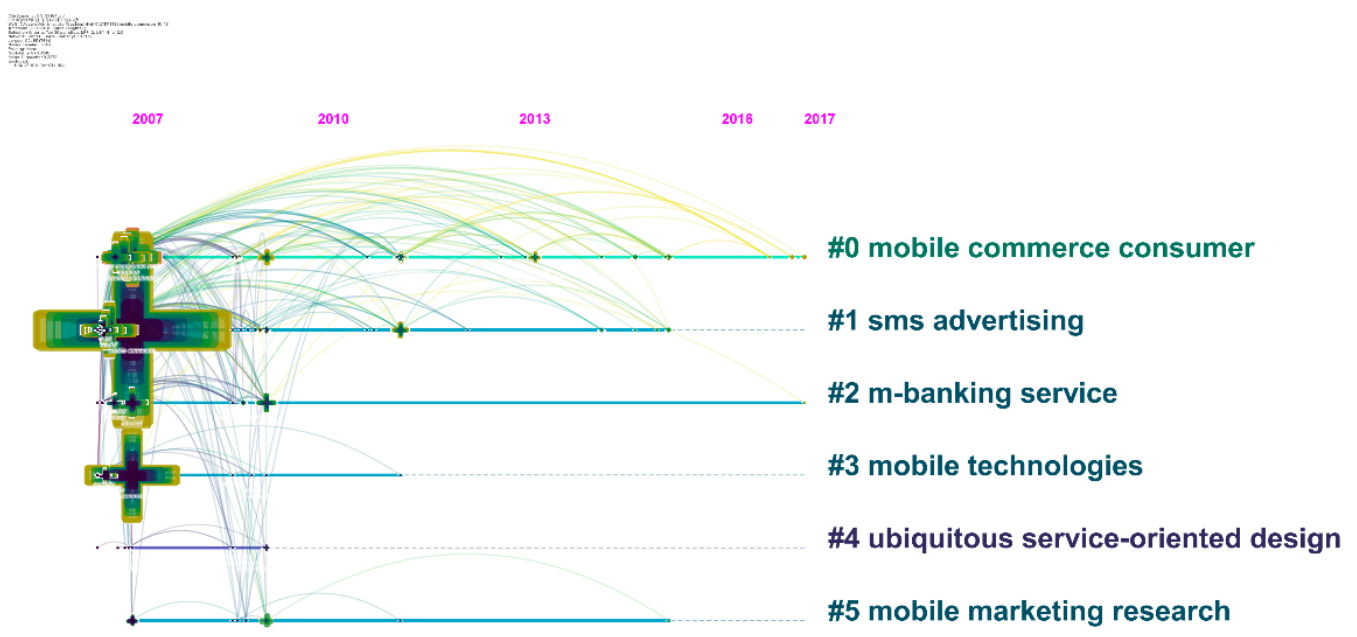

Figure 9. Collaborative Citation Timeline visualization map.

We summarized the cluster ID and details in Table 12. Size represents the number of articles. Mean year indicates average year of the cluster, label is the main content contained in this cluster. It can be seen from the Table 12, cluster ID\#0 is the largest cluster with 29 articles. The most typical cited article is "An empirical examination of factors influencing the intention to use mobile payment. "The second one is Cluster ID\#1 wit 27 articles. The most typical cited article is "User acceptance of hedonic digital artifacts: a theory of consumption values perspective." The third one is Cluster\#2 and Cluster\#3 with 13 articles. This is followed by "ubiquitous service-oriented design" (Cluster ID\#4) and "mobile marketing research" (Cluster ID\#5), they have 11 members and 7 members, respectively. The most typical cited article is "ubiquitous service-oriented design of $3 \mathrm{~g} / 4 \mathrm{~g}$ mobile commerce. Another typical cited article is "Mobile marketing research:the state of the art."

Table 12. Common Citation Clusters for mobile commerce.

\begin{tabular}{|c|c|c|c|}
\hline Cluster ID & Size & Mean (Year) & Label \\
\hline$\# 0$ & 29 & 2012 & $\begin{array}{l}\text { (0.03) e-commerce; }(0.06) \text { security; }(0.03) \text { mobilecommunication; } \\
\text { (0.08)authentication; }(0.03) \text { mobile; }(0.01) \text { privacy; }(0.02) \text { network; } \\
(0.01) \text { mobiledevice; }(0.01) \text { consumer behaviour; }(0.02) \text { m-payment; } \\
(0.08) \text { technology acceptance model; }\end{array}$ \\
\hline$\# 1$ & 27 & 2011 & $\begin{array}{l}(0.14) \text { information technology; }(0.10) \text { user acceptance; }(0.03) \\
\text { customer satisfaction; }(0.04) \text { behavioral intention; }(0.01) \text { planned } \\
\text { behavior; }(0.03) \text { perceived risk; }(0.02) \text { perceived usefulness; }(0.01) \\
\text { empirical analysis; }(0.02) \text { m-commerce adoption }\end{array}$ \\
\hline \#2 & 13 & 2009 & $\begin{array}{l}(0.08) \text { model; }(0.08) \text { adoption; }(0.10) \text { internet; }(0.06) \text { service; }(0.12) \\
\text { technology; }(0.06) \text { acceptance; }(0.03) \text { online; }(0.03) \text { banking; }(0.02) \\
\text { mobile payment system; }(0.01) \text { game theory }\end{array}$ \\
\hline$\# 3$ & 13 & 2009 & $\begin{array}{l}(0.06) \text { trust; }(0.09) \text { determinant; }(0.08) \text { satisfation; }(0.05) \\
\text { e-commerce; }(0.01) \text { mobilepayment; }(0.01) \text { quality; }(0.01) \text { loyalty; } \\
(0.01) \text { service quality; }(0.01) \text { mobile banking; }(0.01) \text { social influence; } \\
\text { (0.01) web site; }(0.01) \text { location-based service; }(0.01) \text { expectation } \\
\text { confirmation model }\end{array}$ \\
\hline$\# 4$ & 11 & 2008 & $\begin{array}{l}(0.02) \text { framwork; }(0.03) \text { information system; }(0.01) \text { mobile service; } \\
(0.01) \text { performance; }(0.01) \text { intrinsic motivation; }(0.01) \text { market; } \\
\text { (0.01) design aesthetics; }(0.01) \text { fit index }\end{array}$ \\
\hline \#5 & 7 & 2010 & $\begin{array}{l}(0.08) \text { involvement; }(0.07) \text { attitude; }(0.02) \text { mobile advertising; }(0.02) \\
\text { mobile marketing }\end{array}$ \\
\hline
\end{tabular}


We divided the cluster into three categories according to time period. As can be seen in Table 13, the clusters ID\#2, clusters ID\#3 and clusters ID\#4 are divided into 2008-2009 (3), the clusters ID\#1 and clusters ID\#5 are divided into 2010-2011 (2). the clusters ID\#0 are divided into 2012 (1). On the basis of the analysis above, we may draw a conclusion that the research trend of mobile commerce have transformed from technologies to marketing (mobile commerce consumer acceptance, mobile advertising). The current research focuses on mobile commerce consumer, for example, consumer behaviour and continuance intention [41].

Table 13. Article cluster ID, label and average year.

\begin{tabular}{lll}
\hline Mean Year (Range) & Number of Cluster & Cluster ID and Labels \\
\hline $2008-2009$ & 3 & $\begin{array}{l}\text { m-banking service (\#2, 2009); mobile technologies (\#3, 2009); } \\
\text { ubiquitous service-oriented design (\#4,2008) }\end{array}$ \\
\hline $2010-2011$ & 2 & sms advertising (\#1, 2011); mobile marketing research (\#5, 2012) \\
\hline 2012 & 1 & mobile commerce consumer (\#0, 2010) \\
\hline
\end{tabular}

\subsection{Analysis on the Factors from Abstracts}

In Table 14, we listed key terms with high frequency selected by the software and separated key terms as independent variable and dependent variable. The independent variable is regarded as the factors that may result in the dependent variable changes. The independent variable is a variable manipulated and controlled by the experimenter. The changes and results caused by independent variables are called dependent variables. Independent variables and dependent variables are interdependent. We classified the key terms depending on the attributes of the dependent and independent variables. After screening, we retained 24 key terms as independent variable. Meanwhile we selected 11 key terms as dependent variable. Table 14 summarizes the result and commonly used theories in mobile commerce. These theories provide the theoretical basis for the framework.

Table 14. The key terms in abstract.

\begin{tabular}{lll}
\hline Independent Variable & Dependent Variable & Theory \\
\hline Service quality & Purchase intention & Technology acceptance model \\
Perceived risk & Trust & Game theory \\
Information quality & Satisfaction & Empirical analysis \\
Design & Buying behavior & Expectation confirmation model \\
System quality & Consumer behavior & Unified theory \\
Information system & Purchase intention & Commitment-trust theory \\
Perceived usefulness & Word of mouth & Decision-making process \\
Design aesthetics & loyalty & Innovation diffusion theory \\
Information technology & User acceptance & TRA \\
Mobile service & Decision making & Network externality theory \\
Web & M-commerce adoption & Interpretive structural model \\
Network & & Neural network \\
Social influence & SVM \\
Cloud computing & & \\
Decision makers & & \\
Mobile users & & \\
Social value & & \\
Application & & \\
LBS & & \\
RFID & & \\
Mobile Interface & \\
Legal & & \\
Information interaction & & \\
Intellectual property & & \\
\hline
\end{tabular}


We put the independent variables into four dimension of the model (I-model) according to the different nature. I-Modelpresent a conceptual framework and uncover some information that were missing. Meanwhile it has important implications to prompt future research directions. Technology, people, organization/society and information are four-dimension of I-modelis. Information is a subject of communication technologies. Technology provide support to computer science and engineering, people is ultimately one of the major driving factors, society is a platform to share knowledge and value, for example, working groups, organizations and governments. We analyze the key terms. As shown in Figure 10, the framework of mobile commerce researches has been presented, which has directive significance to our future research. Firstly, we help scholars extend their studies by dividing the independent variable into four dimensions of I-model. Secondly, people factor should be a focus in m-commerce field. a lot of key terms with high frequency are related to consumer acceptance. Thirdly, most theories in mobile commerce are derived from e-commerce area. Relevant researchers should integrate the original theory and explore more theoretical model to enrich the insights of mobile commerce.

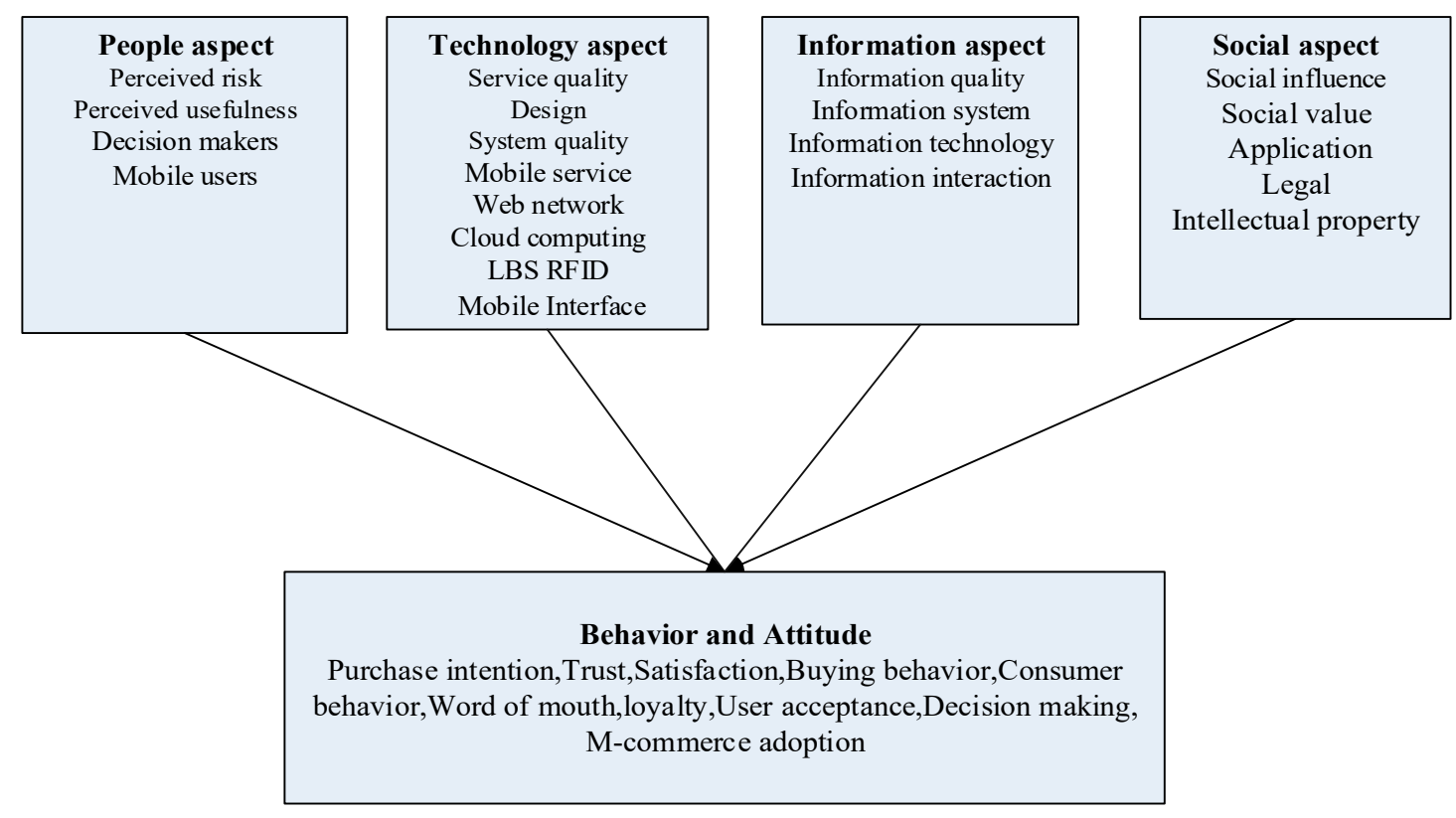

Theories in Mobile Commerce

Technology acceptance model,Game theory,Empirical analysis,Expectation confirmation model,Unified theory,Commitment-trust theory,Decision-making process, TRA,Network externality theory,Interpretive structural model, Neural network,SVM

Figure 10. The integrated framework of mobile commerce researches.

\section{Discussion}

We analyzed the 1130 core publications with 25,502 associated references by using CiteSpace. We analyzed literature data from the following various items (e.g., author, citied author, institution, country, reference, journal, keyword and key term). In order to understand the research trend of mobile commerce in the timeline, we use the strength of citation bursts and timeline view to analyze keywords. We extracted key information from abstracts and mapped result into the I-Modelwhich provided important framework to classify m-commerce activities and theories. Some useful outcomes based on the above analysis are presented as follows:

(1) The publications grow linearly from 2012. Mainly because of the wireless network technology and huge mobile users. However, with an explosion of m-commerce APP, there are some challenges 
that cannot be anticipated by $4 \mathrm{G}$, such as the spectrum crisis and high energy consumption. We have to face the continuously increasing demand for high data rates and mobility required by $\mathrm{m}$-commece users. The $5 \mathrm{G}$ technologies are expected to be deployed by wireless system designers beyond 2020, such as massive MIMO, energy-efficient communications [42,43]. RFID is a technology which can be employed to complete payment functions on m-commerce. The related security of RFID is very important [44]. The ultra-lightweight RFID authentication scheme ia proposed to improve m-commerce [45].

(2) The top three productive countries and territories were China, TAIWAN and USA. Table 7 and Figure 5 show the complete list. Huazhong Univ Sci \& Technol is the most productive academic institution. Professor Zhang at Huazhong Univ Sci \& Technol is the strongest research team in $\mathrm{m}$-commerce field. His research subject focused on mobile service value chain, TAM extension and m-commerce risk [46-49].

(3) The keywords are divided into 6 clusters in Figure 9. The papers within these clusters are similar to the intellectual base of the subfield which can be labeled as the cluster label. We obtained four major clusters of research by mutual information, namely mobile commerce consumer, $\mathrm{m}$-banking service, mobile technologies and mobile marketing research. In order to discover the research fronts. We collected the papers with high frequency in the cluster and citing papers were tracked. For example, Table 15 shows that the first largest cluster has 29 papers as its intellectual base. This cluster is concerned with the applications of the SEM-neural networks methods for the purpose of $\mathrm{m}$-commerce adoption. The papers which cite elements of this cluster can be viewed as research fronts. For example, the work in the 94th reference can be considered as a current research front which builds on the intellectual base of SEM-neural networks methods for customer satisfaction.

Table 15. Articles of the major clusters and their citing papers.

\begin{tabular}{llclcc}
\hline & \multicolumn{2}{c}{ Cluster } & \multicolumn{2}{c}{ Intellectual Base } & \multicolumn{2}{c}{ Research Fronts } \\
\hline Cluster ID & \multicolumn{1}{c}{ MI } & Total & Papersin the Cluster & Total & Citing Papers \\
\hline$\# 0$ & Mobile commerce consumer & 29 & {$[7,49-76]$} & 19 & {$[39,77-94]$} \\
\hline$\# 2$ & m-banking service & 13 & {$[95-107]$} & 11 & {$[86-93,108-110]$} \\
\hline$\# 3$ & mobile technologies & 13 & {$[4,42,44,111-120]$} & 8 & {$[45,121-127]$} \\
\hline$\# 5$ & mobile marketing research & 7 & {$[115-118,128-130]$} & 5 & {$[131-135]$} \\
\hline
\end{tabular}

MI: Cluster Labels using Mutual Information.

\section{Conclusions}

\subsection{Suggestions for Research}

We provided important framework to classify m-commerce activities and theories based on visual analysis and I-model. The most common model is TAM and the articles from JH Wu and SC Wang illustrates this point. We have reasons to believe that TAM is the main model in estimating mobile commerce acceptance. ECM and TRA are another important models, other theoretical mode was rarely used. as shown in Figure 10. Chong found that the neural network method is more practical in predicting the adoption behavior of $\mathrm{m}$-commerce users [76]. As a supplementary content support TAM [136]. SEM-neural networks methods can increase the accuracy of the measure [39]. Compared with the neural network method, SVM take global variables into account. We can introdece SVM into mobile commerce acceptance model [137]. Most of the research discovered the key influence factor of consumer acceptance behavior. Zhang LY indicated that culture is regulating variable of mobile commerce adoption by using structural equation model. There are some factors that are not taken into account, such as individual emotions, situational awareness, psychological activities and multiple environment $[52,138]$. In addition, there is no segmentation of user groups. 
More research should to be conducted on m-commerce consumers with different backgrounds, such as enterprise users, rural residents, student groups, middle-aged and elderly users. Social commerce and cross-border e-commerce have potential become research focus in the future through the above analysis. We can apply social marketing into m-commerce to make more profit for enterprises. In the context of One Belt And One Road strategy, we should promote the integration of mobile payment and cross-border e-commerce. Identify cross-border e-commerce platform risks under m-commerce environment. We need to accelerate mobile logistics goods tracking and mobile office to promote smart city construction. More artificial intelligence elements should be introduced into mobile commerce application. However, technical problems and soft tools are two constraints in the process [139].

\subsection{Methodological Contributions}

We use CiteSpace to analyze the the limitations of current research and future research direction. Compared with the existing literature review of mobile commerce, we made a set of knowledge maps to show the future trends of mobile commerce and analyzed visual results based on I-model. It is the first study to put forward the major clusters to reveal their associated intellectual bases and research fronts, as shown in Table 15. The result of research enriched bibliometric analysis method and extended types of literature review. this method can be applied in other areas through searching different keywords. It also provides perspectives to researchers how to use a software to analyze articles and make knowledge mapping. This method can help researchers to grasp the evolution of a specific field, such as social commerce, cross-border e-commerce and $\mathrm{O} 2 \mathrm{O}$ business model.

\subsection{Practical Contributions}

We have divided the key terms into four different dimensions of I-model. They are information, people, technology and social. The gap between theoretical research and reality is found, we proposed the new issues of mobile commerce. From the information aspect, in the era of big data, the information from mobile terminal is valuable, the personal information data will heip merchant have better understanding of customers. More artificial intelligence should be introduced to analyze the preference information from consumer. In addition, because of limited page capacity. It has obvious disadvantages in information display. It is difficult to convert on the same page. Therefore, the information is classified scientifically can improve shopping experience on mobile terminal. A folding screen for mobile device can improve the quality of information display. From the people aspect, we found that perceived ease of use, perceived usefulness and perceived risk may influence consumer satisfaction [140]. Trust plays an important role for potential user to adopt mobile commerce systems. In order to help the consumer trust the dealer and the service supplier. We can select a distinct layout that can be used in digital signage for publicity. In addition, the management system based on trust should be established to assess risk levels and eliminate malicious nodes [141]. From the dimension of technology, 5G will improve network speed and allow more mobile commerce users to access. The improvement of RFID made mobile payment more convenient and safer. LBS for mobile commerce can lead market share growth, especially in the $\mathrm{O} 2 \mathrm{O}$ model $[112,142]$. Internet of Things technologies will provide new opportunities to mobile commerce. In addition, corresponding mobile interfaces, website design, system quality need to be improved by practitioners in order to satisfy the requirements of users. Because these aspects will determine the consumer purchase behavior and bring new social value. From the dimension of social, the practitioners should not only focus on the field of mobile shopping service. The applications on other fields require attention, such as telemedicine, $\mathrm{m}$-tourism, rescue [143]. The interrelate law and regulations should be established to protect the m-commerce environment. In a word, four dimensions are inseparable. Each dimensions and its associated measures make up the critical factors of mobile commerce. 


\subsection{Limitations and Future Research}

The limitations of the paper are listed. Firstly, many authors cite their own articles which may affect co-citation analysis results. we might try to reduce this effect by eliminating the self-citations. Secondly, all sample collection from databases abroad, if increases database from multiple languages may lead different results from CiteSpace., China is a productive country in the fields of mobile commerce. Future research may consider that collect samples through Chinese database called CNKI. It can make different result based on my method. Thirdly, co-citation analysis is process with a lag time. Some new literatures have not entered the database for retrieval. Future research will focus on overcoming the limitations and combining with the most advanced literature analysis method to extend m-commerce research.

Author Contributions: Authors contributed equally to the conceptualization of the study. S.D. wrote the paper and was predominantly responsible for carrying out the data analysis. H.L. wrote the paper and was predominantly responsible for carrying out the result interpretive. S.D. and H.L. were finalized the paper for submission.

Funding: This research received no external funding.

Acknowledgments: We would like to thank the editor and the anonymous reviewers for their comments, which have greatly improved our paper.

Conflicts of Interest: The authors declare no conflict of interest.

\section{References}

1. Turban, E.; Outland, J.; King, D.; Lee, J.K.; Liang, T.P.; Turban, D.C. Mobile Commerce and the Internet of Things. In Electronic Commerce 2018; Springer: Cham, Switzerland, 2018.

2. Sun, J.; Chi, T. Key factors influencing the adoption of apparel mobile commerce: An empirical study of Chinese consumers. J. Text. Inst. 2017, 109, 785-797. [CrossRef]

3. Wu, Q.; Li, G.Y.; Wen, C.; Ng, D.W.K.; Schober, R. An Overview of Sustainable Green 5 G Networks. IEEE Wirel. Commun. 2017, 24, 72-80. [CrossRef]

4. Alsharif, M.H.; Nordin, R.; Abdullah, N.F.; Kelechi, A.H. How to make key 5G wireless technologies environmental friendly: A review. Trans. Emerg. Telecommun. Technol. 2018, 29, e3254. [CrossRef]

5. Thongpapanl, N.; Ashraf, A.R.; Lapa, L. The Potential Benefits of Offering Suitable Mobile Commerce Experience to Your Customers: An Abstract. In Proceedings of the Academy of Marketing Science Conference, Coronado, CA, USA, 24-26 May 2017; p. 719.

6. Ngai, E.W.T.; Gunasekaran, A. A review for mobile commerce research and applications. Decis. Support Syst. 2007, 43, 3-15. [CrossRef]

7. Wu, X.; Qi, C.; Zhou, W.; Guo, J. A review of Mobile Commerce consumers' behaviour research: Consumer acceptance, loyalty and continuance (2000-2009). Int. J. Mob. Commun. 2010, 8, 528-560. [CrossRef]

8. Saura, J.R.; Palos-Sánchez, P.; Cerdá Suárez, L.M. Understanding the digital marketing environment with KPIs and web analytics. Future Internet 2017, 9, 76. [CrossRef]

9. Kwon, O.B.; Sadeh, N. Applying case-based reasoning and multi-agent intelligent system to context-aware comparative shopping. Decis. Support Syst. 2004, 37, 199-213. [CrossRef]

10. Chantzaras, A.; Dimitrios, N.K.; Vlachos, D.S. Mobile Commerce and Success Factors. Simulation and Modeling of the Problem. In Strategic Innovative Marketing; Springer: Cham, Switzerland, 2017.

11. Varshney, U.; Vetter, R. Mobile Commerce: Framework, Applications and Networking Support; Springer: New York, NY, USA, 2002; pp. 185-198.

12. Balasubramanian, S.; Peterson, R.A.; Jarvenpaa, S. Exploring the Implications of M-Commerce for Markets and Marketing. J. Acad. Mark. Sci. 2002, 30, 348-361. [CrossRef]

13. Gerpott, T.J.; Thomas, S. Empirical research on mobile Internet usage: A meta-analysis of the literature. Telecommun. Policy 2014, 38, 291-310. [CrossRef]

14. Martín, S.S.; López-Catalán, B.; Ramón-Jerónimo, M.A. Factors determining firms' perceived performance of mobile commerce. Ind. Manag. Data Syst. 2013, 112, 946-963. [CrossRef]

15. Li, X.X.; Shen, J. Visualization Analysis on Key Technologies of Technical Evolution-In the Field of 3G Mobile Communication. Adv. Mater. Res. 2013, 694-697, 2394-2399. [CrossRef] 
16. Wong, L.H.; Looi, C.K. What seams do we remove in mobile-assisted seamless learning? A critical review of the literature. Comput. Educ. 2011, 57, 2364-2381. [CrossRef]

17. Saura, J.R.; Palos-Sanchez, P.R.; Correia, M.B. Digital Marketing Strategies Based on the E-Business Model: Literature Review and Future Directions. In Organizational Transformation and Managing Innovation in the Fourth Industrial Revolution; IGI Global: Hershey, PA, USA, 2019; pp. 86-103.

18. Liu, D.; Zhang, J.; Liu, S. Visualization analysis of research hotspots based on CiteSpace II: Taking medical devices as an example. Med. Dev. Evid. Res. 2014, 7, 357-361. [CrossRef]

19. Hou, J.; Hu, Z. Review on the Application of CiteSpace at Home and Abroad. J. Mod. Inf. 2013, 33, 99-103.

20. Chen, C. Mapping Scientific Frontiers; Springer: London, UK, 2013.

21. Zhang, P.; Wang, C. The Evolution of Social Commerce: An Examination from the People, Business, Technology, and Information Perspective. Commun. AIS 2012, 31, 105-127.

22. Zhang, P.; Benjamin, R.I. Benjamin, and Technology, Understanding information related fields: A conceptual framework. J. Am. Soc. Inf. Sci. Technol. 2010, 58, 1934-1947. [CrossRef]

23. Baskerville, R.L.; Myers, M.D. Information Systems as a Reference Discipline. MIS Q. 2002, 26, 1-14. [CrossRef]

24. Tan, T.S.; John, F.; Zainol, F.A. An Integrated View of Knowledge Management Enablers, Process and Organizational Performance in Malaysian Enterprises. Asian Inst. Knowl. Manag. 2017, 1, 40.

25. Varshney, U. The Status and Future of 802.11-Based WLANs. Computer 2003, 36, 102-105. [CrossRef]

26. Ellis, D.; Allen, D.; Wilson, T. Information Science and Information Systems: Conjuct Subjects Disjunct Disciplines; John Wiley \& Sons, Inc.: Hoboken, NJ, USA, 1999; pp. 1095-1107.

27. Zhao, Y.; Zhu, Q. Evaluation on crowdsourcing research: Current status and future direction. Inf. Syst. Front. 2014, 16, 417-434. [CrossRef]

28. Yi, C.; Jian, M.; Liu, Y. Knowledge mapping of social commerce research: A visual analysis using CiteSpace. Electron. Commer. Res. 2018, 18, 837-868.

29. Chen, C. CiteSpace II: Detecting and visualizing emerging trends and transient patterns in scientific literature. J. Assoc. Inf. Sci. Technol. 2006, 57, 359-377. [CrossRef]

30. Ailawadi, K.L.; Beauchamp, J.; Donthu, N.; Gauri, D.K.; Shankar, V. Communication and Promotion Decisions in Retailing: A Review and Directions for Future Research. J. Retail. 2009, 85, 42-55. [CrossRef]

31. Chen, D.; Liu, Z.; Luo, Z.; Webber, M.; Chen, J. Bibliometric and visualized analysis of emergy research. Ecol. Eng. 2016, 90, 285-293. [CrossRef]

32. Tsu Wei, T.; Marthandan, G.; Yee-Loong Chong, A.; Ooi, K.B.; Arumugam, S. What drives Malaysian m-commerce adoption? An empirical analysis. Ind. Manag. Data Syst. 2009, 109, 370-388. [CrossRef]

33. Venkatesh, V.; Ramesh, V.; Massey, A.P. Understanding usability in mobile commerce. Commun. ACM 2003, 46, 53-56. [CrossRef]

34. Chong, Y.L.; Chan, F.T.S.; Ooi, K.B. Predicting consumer decisions to adopt mobile commerce: Cross country empirical examination between China and Malaysia. Decis. Support Syst. 2012, 53, 34-43. [CrossRef]

35. Li, Y.-M.; Yeh, Y.-S. Increasing trust in mobile commerce through design aesthetics. Comput. Hum. Behav. 2010, 26, 673-684. [CrossRef]

36. Zhang, L.; Zhu, J.; Liu, Q. A meta-analysis of mobile commerce adoption and the moderating effect of culture. Comput. Hum. Behav. 2012, 28, 1902-1911. [CrossRef]

37. Gefen, D.; Straub, E.K.W. Trust and TAM in Online Shopping: An Integrated Model. MIS Q. 2003, 27, 51-90. [CrossRef]

38. Hsu, C.-L.; Lu, H.-P. Why do people play on-line games? An extended TAM with social influences and flow experience. Inf. Manag. 2004, 41, 853-868. [CrossRef]

39. Hew, T.-S.; Leong, L.-Y.; Ooi, K.-B.; Chong, A.Y.-L. Predicting Drivers of Mobile Entertainment Adoption: A Two-Stage SEM-Artificial-Neural-Network Analysis. J. Comput. Inf. Syst. 2016, 56, 352-370. [CrossRef]

40. Hung, C.L.; Chou, J.C.L.; Chung, R.; Dong, T.P. A cross-cultural study on the mobile commerce acceptance model. In Proceedings of the IEEE International Conference on Management of Innovation \& Technology, Singapore, 2-5 June 2010.

41. Ijaz, M.F.; Rhee, J. Constituents and consequences of Online-shopping in Sustainable E-Business: An experimental study of Online-Shopping Malls. Sustainability 2018, 10, 3756. [CrossRef]

42. Zhang, S.; Wu, Q.; Xu, S.; Li, G.Y. Fundamental Green Tradeoffs: Progresses, Challenges, and Impacts on 5G Networks. IEEE Commun. Surv. Tutor. 2017, 19, 33-56. [CrossRef] 
43. Li, Y.U.; Zhang, Z.; Cheng, F.; Haonan, H.U. Cellular architecture and key technologies for 5G mobile communication networks. J. Chongqing Univ. Posts Telecommun. 2014, 52, 122-130.

44. Li, T.; Wang, G. Security Analysis of Two Ultra-Lightweight RFID Authentication Protocols. IFIP Int. Fed. Inf. Process. 2007, 232, 109-120.

45. Kai, F.; Nan, G.; Gong, Y.; Hui, L.; Su, R.; Yang, Y. An ultra-lightweight RFID authentication scheme for mobile commerce. Peer-to-Peer Netw. Appl. 2016, 10, 1-9.

46. Man, Q.S.; Liu, X.C.; Zhang, J.L. A game-theory analysis of a multi-channel strategy in the mobile service value chain. In Proceedings of the International Conference on Management Science \& Engineering, Harbin, China, 17-19 July 2013.

47. Deng, Z.; Liang, Z.; Zhang, J. Applying Technology Acceptance Model to Explore the Determinants of Mobile Health Service: From the Perspective of Public User. In Proceedings of the Eleventh Wuhan International Conference on e-Business, Wuhan, China, 26-27 May 2012.

48. Chong, X.; Zhang, J.L.; Lai, K.K.; Nie, L. An Empirical Analysis of Mobile Internet Acceptance from Value-based View. Int. J. Mob. Commun. 2012, 10, 536-557. [CrossRef]

49. Deng, Z.; Lu, Y.; Wang, B.; Zhang, J.; Wei, K.K. An empirical analysis of factors influencing users' adoption and use of mobile services in China. Int. J. Mob. Commun. 2010, 8, 561-585. [CrossRef]

50. Bruner, G.I.; Kumar, A. Explaining consumer acceptance of handheld Internet devices. J. Bus. Res. 2005, 58, 553-558. [CrossRef]

51. Novak, T.P.; Hoffman, D.L.; Yung, Y.-F. Measuring the Customer Experience in Online Environments: A Structural Modeling Approach. Mark. Sci. 2000, 19, 22-42. [CrossRef]

52. Chen, G.; Kotz, D. A Survey of Context-Aware Mobile Computing Research; Department of Computer Science, Dartmouth College: Hanover, NH, USA, 2000; pp. 125-126.

53. Wu, T.J.; Zhao, R.H.; Tzeng, S.Y. An empirical research of consumer adoption behavior on catering transformation to mobile O2O. J. Interdiscip. Math. 2015, 18, 769-788. [CrossRef]

54. Barnes, S.J. The mobile commerce value chain: Analysis and future developments. Int. J. Inf. Manag. 2002, 22, 91-108. [CrossRef]

55. Benou, P. Context management for m-commerce applications: Determinants, methodology and the role of marketing. Inf. Technol. Manag. 2012, 13, 91-111. [CrossRef]

56. Ding, X.; Yong, T. A study on adoption behavior of mobile commerce consumer based on TAM-MIA. In Proceedings of the IEEE International Conference on Progress in Informatics \& Computing, Shanghai, China, 10-12 December 2010.

57. Lee, S.F.; Tsai, Y.C.; Jih, W.J.K. An Empirical Examination of Customer Perceptions of Mobile Advertising. Inf. Resour. Manag. J. 2006, 19, 39-55. [CrossRef]

58. Tang, M.L.; Kuo, C.W. Toward an Integrative Model for Consumer Behavior regarding Mobile Commerce Adoption. In Proceedings of the International Conference on Cyber-enabled Distributed Computing \& Knowledge Discovery, Huangshan, China, 10-12 October 2010.

59. Pedersen, P.E. Adoption of Mobile Internet Services: An Exploratory Study of Mobile Commerce Early Adopters. J. Organ. Comput. 2005, 15, 203-222. [CrossRef]

60. Siau, K.; Shen, Z. Building customer trust in mobile commerce. Commun. ACM 2003, 46, 91-94. [CrossRef]

61. Wu, J.H.; Wang, S.C. What drives mobile commerce? An empirical evaluation of the revised technology acceptance model. Inf. Manag. 2005, 42, 719-729. [CrossRef]

62. Yang, K.C.C. Exploring factors affecting the adoption of mobile commerce in Singapore. Telemat. Inform. 2005, 22, 257-277. [CrossRef]

63. Alshaali, S.; Varshney, U. On the usability of mobile commerce. Int. J. Mob. Commun. 2005, 3, 29-37. [CrossRef]

64. Anil, S.; Ting, L.T.; Moe, L.H.; Jonathan, G.P.G. Overcoming barriers to the successful adoption of mobile commerce in Singapore. Int. J. Mob. Commun. 2003, 1, 194-231. [CrossRef]

65. Cao, Y.; Lu, Y.; Gupta, S.; Yang, S. The effects of differences between e-commerce and m-commerce on the consumers' usage transfer from online to mobile channel. Int. J. Mob. Commun. 2015, 13, 51-70. [CrossRef]

66. Choi, J.; Seol, H.; Cho, H.; Lee, S.; Park, Y. Customer satisfaction factors of mobile commerce in Korea. Internet Res. 2013, 18, 313-335. [CrossRef] 
67. Chung, K.C. Gender, culture and determinants of behavioural intents to adopt mobile commerce among the Y Generation in transition economies: Evidence from Kazakhstan. Behav. Inf. Technol. 2014, 33, 743-756. [CrossRef]

68. Khansa, L.; Zobel, C.W.; Goicochea, G. Creating a Taxonomy for Mobile Commerce Innovations Using Social Network and Cluster Analyses. Int. J. Electron. Commer. 2012, 16, 19-52. [CrossRef]

69. Lee, T.M.; Jun, J.K. The role of contextual marketing offer in Mobile Commerce acceptance: Comparison between Mobile Commerce users and nonusers. Int. J. Mob. Commun. 2007, 5, 339-356. [CrossRef]

70. Li, M.; Dong, Z.Y.; Chen, X. Factors Influencing Consumption Experience of Mobile Commerce: A Study from Experiential View. Internet Res. 2012, 22, 120-141. [CrossRef]

71. Lin, J.; Wang, B.; Wang, N.; Lu, Y. Understanding the evolution of consumer trust in mobile commerce: A longitudinal study. Inf. Technol. Manag. 2014, 15, 37-49. [CrossRef]

72. Lin, Y.M.; Shih, D.H. Deconstructing mobile commerce service with continuance intention. Int. J. Mob. Commun. 2008, 6, 67-87. [CrossRef]

73. Okazaki, S.; Mendez, F. Exploring convenience in mobile commerce: Moderating effects of gender. Comput. Hum. Behav. 2013, 29, 1234-1242. [CrossRef]

74. Shih, Y.Y.; Chen, C.Y. The study of behavioral intention for mobile commerce: Via integrated model of TAM and TTF. Qual. Quant. 2013, 47, 1009-1020. [CrossRef]

75. Vrechopoulos, A.; Constantiou, I.; Doukidis, G.; Mylonopoulos, N.; Sideris, I. The critical role of consumer behaviour research in mobile commerce. Int. J. Mob. Commun. 2003, 1, 239-340. [CrossRef]

76. Chong, Y.L. A two-staged SEM-neural network approach for understanding and predicting the determinants of m-commerce adoption. Expert Syst. Appl. 2013, 40, 1240-1247. [CrossRef]

77. Wang, S.W.; Ngamsiriudom, W.; Hsieh, C.H. Trust disposition, trust antecedents, trust, and behavioral intention. Serv. Ind. J. 2015, 35, 555-572. [CrossRef]

78. Chen, K.Y.; Chang, M.L. User acceptance of 'near field communication' mobile phone service: An investigation based on the 'unified theory of acceptance and use of technology' model. Serv. Ind. J. 2013, 33, 609-623. [CrossRef]

79. Faqih, K.M.S.; Jaradat, M.I.R.M. Assessing the moderating effect of gender differences and individualismcollectivism at individual-level on the adoption of mobile commerce technology: TAM3 perspective. J. Retail. Consum. Serv. 2015, 22, 37-52. [CrossRef]

80. Leong, L.-Y.; Hew, T.-S.; Tan, G.W.-H.; Ooi, K.-B. Predicting the determinants of the NFC-enabled mobile credit card acceptance: A neural networks approach. Expert Syst. Appl. 2013, 40, 5604-5620. [CrossRef]

81. Tan, G.W.-H.; Ooi, K.-B.; Leong, L.-Y.; Lin, B. Predicting the drivers of behavioral intention to use mobile learning: A hybrid SEM-Neural Networks approach. Comput. Hum. Behav. 2014, 36, 198-213. [CrossRef]

82. Chi, T.; Sullivan, Q. How Web site Quality Affects Apparel Mobile Commerce Consumer Satisfaction and Intent to Purchase? A Study of Chinese Consumers. In Chinese Consumers and the Fashion Market; Springer: Singapore, 2018.

83. Kumar, A.; Dash, M.K. Using Fuzzy Delphi and Generalized Fuzzy TOPSIS to Evaluate Technological Service Flexibility Dimensions of Internet Malls. Glob. J. Flex. Syst. Manag. 2017, 18, 153-161. [CrossRef]

84. Mutemararo, A. Effectiveness of Online Purchasing Attributes on Company Performance: A Case of Telone Zimbabwe. Bachelor's Thesis, Midlands State University, Gweru, Zimbabwe, 2017.

85. Ying, S.L.; Heng, P.C.; Ng, T.H.; Cheah, C.S. Customers' online website satisfaction in online apparel purchase: A study of Generation Y in Malaysia. Asia Pac. Manag. Rev. 2016, 21, S1029313215000639.

86. Azfar, A.; Choo, K.K.R.; Lin, L. Android mobile VoIP apps: A survey and examination of their security and privacy. Electron. Commer. Res. 2016, 16, 73-111. [CrossRef]

87. Bandera, C. Value-added service providers for mobile education: Empirical challenges and analytics. Electron. Commer. Res. 2017, 17, 317-333. [CrossRef]

88. Chou, Y.C.; Chuang, H.C.; Shao, B.B.M. The impact of e-retail characteristics on initiating mobile retail services: A modular innovation perspective. Inf. Manag. 2016, 53, 481-492. [CrossRef]

89. Eastin, M.S.; Brinson, N.H.; Doorey, A.; Wilcox, G. Living in a big data world: Predicting mobile commerce activity through privacy concerns. Comput. Hum. Behav. 2016, 58, 214-220. [CrossRef]

90. Heinze, J.; Fischer, P.; Thomann, M. Ladders to m-commerce resistance: A qualitative means-end approach. Comput. Hum. Behav. 2017, 73, 362-374. [CrossRef] 
91. Lee, J.M.; Rha, J.Y. Personalization-privacy paradox and consumer conflict with the use of location-based mobile commerce. Comput. Hum. Behav. 2016, 63, 453-462. [CrossRef]

92. Liébana-Cabanillas, F.; Marinković, V.; Kalinić, Z. A SEM-neural network approach for predicting antecedents of m-commerce acceptance. Int. J. Inf. Manag. 2017, 37, 14-24. [CrossRef]

93. Yen, W.C.; Lin, H.H.; Wang, Y.S.; Shih, Y.W.; Cheng, K.H. Factors affecting users' continuance intention of mobile social network service. Serv. Ind. J. 2018, 2018, 1-21. [CrossRef]

94. Leong, L.-Y.; Hew, T.-S.; Lee, V.-H.; Ooi, K.-B. An SEM-artificial-neural-network analysis of the relationships between SERVPERF, customer satisfaction and loyalty among low-cost and full-service airline. Expert Syst. Appl. Int. J. 2015, 42, 6620-6634. [CrossRef]

95. Isaac, J.T. A lightweight secure mobile Payment protocol for vehicular ad-hoc networks (VANETs). Electron. Commer. Res. 2012, 12, 97-123. [CrossRef]

96. Kauffman, R.J.; Liu, J.; Ma, D. Technology Investment Decision-Making under Uncertainty: The Case of Mobile Payment Systems. Inf. Technol. Manag. 2015, 16, 153-172. [CrossRef]

97. Khalilzadeh, J.; Ozturk, A.B.; Bilgihan, A. Security-related factors in extended UTAUT model for NFC based mobile payment in the restaurant industry. Comput. Hum. Behav. 2017, 70, 460-474. [CrossRef]

98. Kim, C.; Mirusmonov, M.; Lee, I. An empirical examination of factors influencing the intention to use mobile payment. Comput. Hum. Behav. 2010, 26, 310-322. [CrossRef]

99. Liébana-Cabanillas, F.; Muñoz-Leiva, F.; Sánchez-Fernández, J. A global approach to the analysis of user behavior in mobile payment systems in the new electronic environment. Serv. Bus. 2018, 12, 25-64. [CrossRef]

100. Liébana-Cabanillas, F.; Sánchez-Fernández, J.; Muñoz-Leiva, F. The moderating effect of experience in the adoption of mobile payment tools in Virtual Social Networks: The m-Payment Acceptance Model in Virtual Social Networks (MPAM-VSN). Int. J. Inf. Manag. 2014, 34, 151-166. [CrossRef]

101. Liébana-Cabanillas, F.; Sánchez-Fernández, J.; Muñoz-Leiva, F. Antecedents of the Adoption of the New Mobile Payment Systems: The Moderating Effect of Age. Comput. Hum. Behav. 2014, 35, 464-478. [CrossRef]

102. Liu, Y.; Wang, S.; Wang, X. A usability-centred perspective on intention to use mobile payment. Int. J. Mob. Commun. 2011, 9, 541-562. [CrossRef]

103. Oliveira, T.; Thomas, M.; Baptista, G.; Campos, F. Mobile payment: Understanding the determinants of customer adoption and intention to recommend the technology. Comput. Hum. Behav. 2016, 61, 404-414. [CrossRef]

104. Ondrus, J.; Gannamaneni, A.; Lyytinen, K. The impact of openness on the market potential of multi-sided platforms: A case study of mobile payment platforms. J. Inf. Technol. 2015, 30, 260-275. [CrossRef]

105. Pousttchi, K.; Schiessler, M.; Wiedemann, D.G. Proposing a comprehensive framework for analysis and engineering of mobile payment business models. Inf. Syst. E-Bus. Manag. 2009, 7, 363-393. [CrossRef]

106. Yang, L.; Song, Y.; Zhu, P.; Zhu, P.; Zhou, P. Dynamics between the trust transfer process and intention to use mobile payment services: A cross-environment perspective. Inf. Manag. 2011, 48, 393-403.

107. Yang, S.; Lu, Y.; Gupta, S.; Cao, Y.; Zhang, R. Mobile payment services adoption across time: An empirical study of the effects of behavioral beliefs, social influences, and personal traits. Comput. Hum. Behav. 2012, 28, 129-142. [CrossRef]

108. Wahid, F.; Prastyo, D. Politicians' Trust in the Information Technology Use in General Election: Evidence from Indonesia. Procedia Technol. 2013, 11, 374-379. [CrossRef]

109. Mares, I.; Young, L. Buying, Expropriating, and Stealing Votes. Annu. Rev. Polit. Sci. 2016, 19, $267-288$. [CrossRef]

110. San-Martín, S.; Prodanova, J.; Catalán, B.L. What makes services customers say "buy it with a mobile phone"? J. Serv. Mark. 2016, 30, 601-614. [CrossRef]

111. Juels, A. RFID security and privacy: A research survey. IEEE J. Sel. Areas Commun. 2006, 24, 381-394. [CrossRef]

112. Alvarez-Jimenez, M.; Alcazar-Corcoles, M.; Gonzalez-Blanch, C.; Bendall, S.; McGorry, P.; Gleeson, J. Online, social media and mobile technologies for psychosis treatment: A systematic review on novel user-led interventions. Schizophr. Res. 2014, 156, 96-106. [CrossRef]

113. Charitonos, K.; Blake, C.; Scanlon, E.; Jones, A. Museum learning via social and mobile technologies: (How) can online interactions enhance the visitor experience? Br. J. Educ. Technol. 2012, 43, 802-819. [CrossRef] 
114. Giaglis, G.M.; Minis, I.; Tatarakis, A.; Zeimpekis, V. Minimizing logistics risk through real-time vehicle routing and mobile technologies: Research to date and future trends. Int. J. Phys. Distrib. Logist. Manag. 2004, 34, 749-764. [CrossRef]

115. Grant, I.; O'Donohoe, S. Why young consumers are not open to mobile marketing communication. Int. J. Advert. 2007, 26, 223-246. [CrossRef]

116. Heinonen, K.; Strandvik, T. Consumer responsiveness to mobile marketing. Int. J. Mob. Commun. 2006, 5, 603-617. [CrossRef]

117. Jayawardhena, C.; Kuckertz, A.; Karjaluoto, H.; Kautonen, T. Antecedents to permission based mobile marketing: An initial examination. Eur. J. Mark. 2011, 43, 473-499. [CrossRef]

118. Kaplan, A.M. If you love something, let it go mobile: Mobile marketing and mobile social media $4 \times 4$. Bus. Horiz. 2012, 55, 0-139. [CrossRef]

119. Kaplan, R.M.; Stone, A.A. Bringing the laboratory and clinic to the community: Mobile technologies for health promotion and disease prevention. Annu. Rev. Psychol. 2013, 64, 471-498. [CrossRef]

120. Milrad, M. Guest editorial: Wireless and Mobile Technologies in Education. J. Comput. Assist. Learn. 2010, 19, 255-259.

121. Cazarotto, P.H.; Da Costa, C.A.; Righi, R.D.R.; Barbosa, J.L.V. GTTracker: Location-aware hierarchical model for identifying M-commerce business opportunities. Peer-to-Peer Netw. Appl. 2017, 12, 13-31. [CrossRef]

122. Fielder, D.; Tanik, U.J.; Gattaz, C.C.; Tanik, M.; Sobrinho, F. Mobile healthcare delivery: A dynamic environment where healthcare, mobile technology, engineering, and individual lifestyles converge. In Proceedings of the Southeastcon, Charlotte, NC, USA, 30 March-2 April 2017.

123. Madanian, S. The use of e-health technology in healthcare environment: The role of RFID technology. In Proceedings of the International Conference on E-commerce in Developing Countries: With Focus on E-Tourism, Isfahan, Iran, 15-16 April 2016.

124. Su, X.; Gu, R.; Qi, C.; Zhang, X.; Choi, D. Interest degree of products analysis by RFID technology for offline shops marketing optimization. In Proceedings of the Advanced Information Management, Communicates, Electronic \& Automation Control Conference, Xi'an, China, 3-5 October 2017.

125. Zarli, A.; Kazi, A.S.; Hannus, M.; Bourdeau, M. Strat-CON: A strategic vision for future R\&D and innovation in ICT-enhanced construction. In Proceedings of the Technology Management Conference, Sophia-Antipolis, France, 4-6 June 2016.

126. Kshetri, N. 5G in E-Commerce Activities. IT Prof. 2018, 20, 73-77. [CrossRef]

127. Mukherjee, A.; De, D. Location management in mobile network: A survey. Comput. Sci. Rev. 2016, 19, 1-14. [CrossRef]

128. Shankar, V.; Venkatesh, A.; Hofacker, C.; Naik, P. Mobile Marketing in the Retailing Environment: Current Insights and Future Research Avenues. J. Interact. Mark. 2010, 24, 111-120. [CrossRef]

129. Varnali, K.; Toker, A. Mobile marketing research: The-state-of-the-art. Int. J. Inf. Manag. 2010, 30, $144-151$. [CrossRef]

130. Watson, C.; Mccarthy, J.; Rowley, J. Consumer attitudes towards mobile marketing in the smart phone era. Int. J. Inf. Manag. 2013, 33, 840-849. [CrossRef]

131. Tan, G.W.-H.; Lee, V.-H.; Hew, J.-J.; Ooi, K.-B.; Wong, L.-W. The interactive mobile social media advertising: An imminent approach to advertise tourism products and services? Telemat. Inform. 2018, 35, 2270-2288. [CrossRef]

132. Baena, V. Online and mobile marketing strategies as drivers of brand love in sports teams: Findings from Real Madrid. Int. J. Sports Mark. Spons. 2016, 17, 1-18. [CrossRef]

133. Hofacker, C.F.; De Ruyter, K.; Lurie, N.H.; Manchanda, P.; Donaldson, J. Gamification and Mobile Marketing Effectiveness. J. Interact. Mark. 2016, 34, 25-36. [CrossRef]

134. Maduku, D.K.; Mpinganjira, M.; Duh, H. Understanding mobile marketing adoption intention by South African SMEs: A multi-perspective framework. Int. J. Inf. Manag. 2016, 36, 711-723. [CrossRef]

135. Müller, J.M.; Pommeranz, B.; Weisser, J.; Voigt, K.-I. Digital, Social Media, and Mobile Marketing in industrial buying: Still in need of customer segmentation? Empirical evidence from Poland and Germany. Ind. Mark. Manag. 2018, 73, 70-83. [CrossRef]

136. Ajzen, I.; Madden, T.J. Prediction of goal-directed behavior: Attitudes, intentions, and perceived behavioral control. J. Exp. Soc. Psychol. 1986, 22, 453-474. [CrossRef] 
137. Petric, M.; Neskovic, A.; Neskovic, N.; Borenovic, M. SVM-based Models for Mobile Users' Initial Position Determination. J. Navig. 2014, 67, 950-966. [CrossRef]

138. Ettis, S.A.; Abidine, A.B.Z.E. Consumer Behavior in M-Commerce. In Mobile Platforms, Design, and Apps for Social Commerce Advances in E-Business Research; IGI Global: Hershey, PA, USA, 2017; pp. 264-287.

139. Qiang, L.; Diao, L.; Tu, G. The Application of Artificial Intelligence in Mobile Learning. In Proceedings of the International Conference on System Science, Yichang, China, 12-14 November 2010.

140. Ijaz, M.F.; Tao, W.; Kang, Y.-S.; Alfian, G. Efficient Digital Signage-Based Online Store Layout: An Experimental Study. Sustainability 2016, 8, 511. [CrossRef]

141. Boukerche, A.; Ren, Y. A trust-based security system for ubiquitous and pervasive computing environments. Comput. Commun. 2008, 31, 4343-4351. [CrossRef]

142. Jiang, H.Y.; Zeng, J.Q. Marketing Model and Cutting-edge Trends of LBS Based Mobile E-commerce. J. Beijing Univ. Posts Telecommun. 2015, 17, 34-39.

143. Saura, J.R.; Palos-Sanchez, P.; Reyes-Menendez, A. Marketing a través de aplicaciones móviles de turismo (m-tourism). Un estudio exploratorio. Int. J. World Tour. 2017, 4, 46-56. [CrossRef]

(C) 2019 by the authors. Licensee MDPI, Basel, Switzerland. This article is an open access article distributed under the terms and conditions of the Creative Commons Attribution (CC BY) license (http://creativecommons.org/licenses/by/4.0/). 